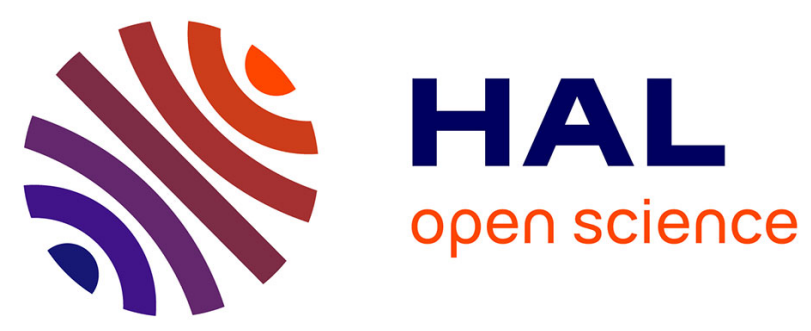

\title{
Post-depositional evolution over a time scale of 1 million years of eastern Mediterranean organic-rich and organic-poor sediments: new insights on the debromination and layer-silicate markers
}

\author{
Anne Murat, Daniel Beaufort, Benoît Hebert, François Baudin, Stefano \\ Bernasconi, Emmanuelle Ducassou, Céline Lelievre, Emmanuel Poizot, \\ Maximilien Mathian, O. Grauby
}

\section{- To cite this version:}

Anne Murat, Daniel Beaufort, Benoît Hebert, François Baudin, Stefano Bernasconi, et al.. Postdepositional evolution over a time scale of 1 million years of eastern Mediterranean organic-rich and organic-poor sediments: new insights on the debromination and layer-silicate markers. Bulletin de la Société Géologique de France, 2017, 188 (4), pp.21. 10.1051/bsgf/2017183 hal-01718064

\section{HAL Id: hal-01718064 https://hal.sorbonne-universite.fr/hal-01718064}

Submitted on 27 Feb 2018

HAL is a multi-disciplinary open access archive for the deposit and dissemination of scientific research documents, whether they are published or not. The documents may come from teaching and research institutions in France or abroad, or from public or private research centers.
L'archive ouverte pluridisciplinaire HAL, est destinée au dépôt et à la diffusion de documents scientifiques de niveau recherche, publiés ou non, émanant des établissements d'enseignement et de recherche français ou étrangers, des laboratoires publics ou privés. 
1 Post-depositional evolution over a time scale of 1 million years of eastern

2 Mediterranean organic-rich and organic-poor sediments: new insights on the

3 debromination and layer-silicate markers

4 Evolution post-dépôt à l'échelle d'un million d'années de sédiments riches et pauvres

5 en matière organique en Méditerranée orientale: nouveaux aperçus sur la

6 débromination et les marqueurs argileux

8 Anne MURAT ${ }^{(1,2)}$, Daniel BEAUFORT ${ }^{(3)}$, Benoît HEBERT ${ }^{(3)}$, François BAUDIN ${ }^{(4)}$, 9 Stefano BERNASCONI ${ }^{(5)}$, Emmanuelle DUCASSOU(6), Céline LELIEVRE ${ }^{(1)}$, 10 Emmanuel POIZOT ${ }^{(1,2)}$, Maximilien MATHIAN ${ }^{(3)}$ and Olivier GRAUBY( ${ }^{(7)}$

11 (1) Laboratoire universitaire des sciences appliquées de Cherbourg. Normandie 12 Univ., UNICAEN, LUSAC, 50100 Cherbourg, France

13 (2) Conservatoire National des Arts et Métiers. INTECHMER, 50100 Cherbourg, 14 France

15 (3) IC2MP UMR 7285, Université de Poitiers, 86073 Poitiers cedex 9, France

16 (4) iSTeP, UMR 7193, Université de Paris VI, 75005 Paris, France

17 (5) Geologisches Institut, ETHZ Zuerich, 8092 Zuerich, Switzerland

18 (6) UMR-CNRS 5805 EPOC, Université de Bordeaux, 33615 Pessac cedex, France

19 (7) UMR 7325 CINaM/CNRS, Université Aix-Marseille campus de Luminy, 13288

20 Marseille cedex 9, France

21 Email: anne.murat@cnam.fr

22

23 Key words: organic matter, clay minerals, bromine, eogenesis, sapropel,

24 Mediterranean sea 
Mots clés : matière organique, minéraux argileux, brome, éogenèse, sapropèle, mer

Méditerranée

Abstract

Organic matter degradation is the engine behind the biogeochemical evolution of sediments during burial. Previous research has shown that eogenesis is the seat of a complex interplay between organic matter, microbes and the most reactive part of inorganic compounds, such as clay minerals. To explore the variability and stability of bromine and clay minerals as geochemical and mineral tracers, we selected an eastern Mediterranean core that has a high degree of stability in the quality and quantity of organic matter through time at a one-million-year scale and great variability in organic matter content at a $10 \mathrm{ky}$ scale. According to the very low maximal burial depth reached by these sediments (the core length is only $36.5 \mathrm{~m}$ ), physical parameters, such as temperature and pressure, did not significantly influence the evolution of the studied parameters during the burial history. The bulk clay mineralogy of organic-rich and organic-poor sediments is similar all along the investigated core material; smectite predominates over kaolinite. The only identified authigenic minerals are biogenetic framboidal pyrite and manganese oxides. The Xray data and the chemical compositions of the smectite are characteristic of a montmorillonite which is representative of a detrital Nile source. At a one-million-year scale, the organic matter content has no significant influence on clay eogenesis, and detrital smectite and kaolinite remain unchanged. Bromine is present in marine organic matter as organobromine compounds. During eogenesis, bromine is released from organic matter as bromide ion, resulting in an increase in the bromide concentration in the pore water with depth. Dissolved bromide can be used as a 
conservative tracer of the debromination of sedimentary organic matter. For the first time, we established that solid-phase BrOrg is a reliable tracer of debromination rates in marine sediments. The rate of debromination depends on the organic matter content. The rate increases from less than $2.3 \times 10^{-4} \mu$ molBrOrg molC $\mathrm{m}^{-1}$ to $6.3 \mathrm{x}$ $10^{-4} \mu$ molBrOrg molC $\mathrm{y}^{-1}$ when TOC varies from 0.17 to $3 \%$. This increase is related to the development of the bacterial population and provides the basis for further investigation of other oceanic basins. For TOC values $>4 \%$, the rate of debromination decreases. We propose that the bioavailability of organic matter is another factor of variability in the debromination rate.

\section{Résumé}

La dégradation de la matière organique est le moteur de l'évolution biogéochimique des sédiments au cours de l'enfouissement. Les recherches précédentes ont montré que l'éogenèse est le siège d'interférences complexes entre la matière organique, les microorganismes et la partie la plus réactive des composés inorganiques comme les minéraux argileux. Pour étudier la variabilité et la stabilité de traceurs géochimiques et minéralogiques, le brome et les minéraux argileux, nous avons choisi une carotte de Méditerranée orientale qui présente une grande stabilité de la qualité et de la quantité de la matière organique à l'échelle de 1 million d'années et une grande variabilité de cette quantité à une échelle de 10 ka. Considérant le faible enfouissement de ces dépôts (la carotte ne fait que 36,5 m de long), les paramètres physiques comme la température et la pression, n'influencent pas significativement l'évolution des paramètres étudiés. La minéralogie des argiles demeure semblable dans toute la carotte, que les sédiments soient riches ou pauvres en matière organique ; la smectite domine sur la kaolinite. Les seuls minéraux authigéniques identifiés sont la pyrite framboïdale biogénique et des oxydes de manganèse. Les 
données de diffraction de rayons $\mathrm{X}$ et la composition chimique de la smectite correspondent à celles d'une montmorillonite représentative des apports détritiques du Nil. A l'échelle de 1 million d'années, la quantité de matière organique n'influence pas l'éogenèse des minéraux argileux, la kaolinite et la smectite détritique demeurent inchangées. Le brome est dans la matière organique marine sous forme de composés organobromés. Pendant l'éogenèse, le brome est libéré de la matière organique sous forme d'ion bromure, il en résulte une augmentation avec l'enfouissement de la concentration en bromure dans l'eau interstitielle. Le bromure dissous peut être utilisé comme un traceur conservatif de la débromination de la matière organique sédimentaire. Pour la première fois, nous avons établi que le brome organique particulaire est un traceur valide du taux de débromination dans les sédiments marins. Le taux de débromination dépend de la quantité de matière organique. II augmente de $2.3 \times 10^{-4} \mu$ molBrOrg molC ${ }^{-1} \mathrm{y}^{-1}$ à $6.3 \times 10^{-4} \mu \mathrm{molBrOrg}$ $\mathrm{molC}^{-1} \mathrm{y}^{-1}$ quand le Carbone Organique Total (COT) varie de 0.17 à $3 \%$. Cette augmentation est en relation avec le développement des populations bactériennes et fournit une base pour l'étude d'autres bassins océaniques. Pour les teneurs en COT $>4 \%$, le taux de débromination diminue. Nous proposons que la biodisponibilité de la matière organique soit un autre facteur de variabilité du taux de débromination.

\section{Introduction}

The early evolution of sediments is an important gap in the fundamental understanding of the eogenetic processes during the very shallow burial of both organic and inorganic matter [Barnes et al., 1990; McKinley et al., 2003; Worden and Morad, 2003; Worden and Burley, 2003]. The term eogenesis covers the very shallow diagenesis of both organic and inorganic matter. Eogenetic mineral reactions include the interaction of detrital mineral assemblages with pore water under the 
100 influence of a depositional system (Burley, 1993). Such reactions proceed at low

101 temperature and are partly biochemical because they occur most often in the

102 bacterial sulfate reduction zone (Barnes et al., 1990, Surdam et al. 1989).Organic

103 matter degradation is the engine behind the biogeochemical evolution of sediments

104 during burial. Field observations primarily target shallow sediment depths and fast-

105 decaying materials, although organic matter, particularly the most refractory

106 compounds, may degrade on geological timescales [Middelburg, 1989; Arndt et al.,

107 2013]. Previous research showed that eogenesis is the seat of a complex interplay

108 between organic matter, microbes and the most reactive part of the inorganic

109 compounds, such as clay minerals. It has been established that organic matter

110 stabilization occurs through the formation of organo-mineral complexes with layer-

111 silicates, such as expandable clays, which are responsible for the reduction in the

112 bioavailability of organic molecules [Mayer, 1994]. Organic matter and bacteria are

113 known to influence the earliest reaction of non-silicates (sulfides, carbonates) and are

114 suspected to have a role during clay eogenesis [Pryor, 1975; Coleman, 1985;

115 Worden and Morad, 2003]. Moreover, because eogenesis is influenced by the

116 residence time of the pore fluids, the early diagenetic assemblages are also

117 governed by the control of sedimentation, such as climate, the rate of subsidence

118 and the rate of sedimentation [Worden and Burley, 2003].

119 The aim of this study is to highlight both the organic matter and layer silicates

120 evolution during eogenesis based on the variability or stability of bromine and clay

121 mineral geochemical tracers.

122 Inorganic bromine is found as soluble bromine salts in seawater, but there are also

123 numerous (200) known organobromine compounds that are synthesized by living

124 organisms or formed during natural abiotic processes, such as forest fires or volcanic 
125

126

eruption [Gribble, 2003]. Bromine is present in marine organic matter as organobromine compounds, and a direct correlation between the bromine content and organic carbon content of sediments has been found by several authors [Price and Calvert, 1977; Pedersen and Price, 1980; Ten Haven et al., 1988; Martin et al., 1993; Ziegler et al., 2008; Leri et al. 2010]. During eogenesis, bromine is released from organic matter as bromide ion, resulting in an increase in the bromide concentration in pore water with depth [Gieskes and Mahn, 2007]. Dissolved bromide can be used as a conservative tracer of the debromination of sedimentary organic matter [Upstill-Goddard and Elderfield, 1988; Mahn and Gieskes, 2001; Berg and Solomon, 2016]. It is generally accepted that the variations in the source of organic matter, supply rate and initial solid-phase bromine concentration make the solidphase bromine concentration an unreliable tracer for debromination in marine sediments [Berg and Solomon, 2016]. We assume that it is possible to calculate the debromination rate based on the solid-phase bromine concentration variability through time.

To achieve this objective and to explore clay mineral evolution, the studied sediment must satisfy certain requirements. The investigated site must display a high degree of stability through time of: (1) the sediment supply characteristics, (2) the sedimentation rate, which must be moderate to provide limited burial, and (3) the quality and quantity of the organic supply at one-million-year scale. However, to investigate the effect of the total organic carbon (TOC) concentration on debromination and clay mineral evolution, large variability in the organic matter content is required at a $10 \mathrm{ky}$ scale.

The sediments of the eastern Mediterranean sea are good candidates to explore the evolution of organic matter during burial and over time. Organic-poor and organic-rich 
150 (sapropels) layers occur periodically in the sedimentary sequences due to a recurrent

151 decline in deep-water ventilation. Sapropels have been the subject of many

152 publications since the 1970s; Meyers [2006] and Rohling et al. [2015] are two of the 153 most recent studies. This study focuses on the Neogene sediments of the Nile 154 margin, which are situated in the far eastern Mediterranean sea, a location that 155 enhances the sapropel layer registration in a smectite-rich sedimentary column.

1562 Material and methods

$157 \quad 2-1$ Material

158 Core MD04 2723 (latitude $32^{\circ} 59.99^{\prime} \mathrm{N}$, longitude $33^{\circ} 08.01^{\prime} \mathrm{E}, 1527 \mathrm{~m}$ water depth, $15936.54 \mathrm{~m}$ long) was collected on the eastern part of the Nile continental margin during 160 the Vanil cruise of Marion Dufresne II in 2004 (Fig. 1). This margin was built by the 161 Nile river, one of the longest rivers in the world with a summer flood regime. Several 162 high magnitude flood periods occurred during the Quaternary, which have been 163 correlated with the periodic intensification of monsoonal activity over the Nile 164 headwaters [Hassan, 1981; Rossignol-Strick, 1985; Emeis et al., 2000; Kallel et al., 165 2000; Schilman et al., 2001]. Nile floods and/or enhanced rainfall over the basin 166 represent significant potential sources of fresh water for the Levantine basin. This 167 fresh water increased the density stratification of the water column and organic 168 matter preservation, and nutrients brought in by the runoff enhanced productivity. 169 These conditions can trigger sapropel deposition [Olausson, 1961; Rohling, 1994; 170 Béthoux and Pierre, 1999; Cramp and O'Sullivan, 1999; Jorissen, 1999; Casford et 171 al., 2003; Meyers, 2006; Rohling et al., 2015]. Sapropels are episodic, basin-wide 172 organic-rich layers that characterize the Neogene sedimentary sequences of the 173 Mediterranean Sea. The classic lithostratigraphy of the eastern Mediterranean is 
174 based on isochronous sapropel deposits, which are synchronous throughout the

175 deep-water basins [Kroon et al., 1998; Kallel et al., 2000; Ducassou et al., 2007].

176 Sapropels were identified in the studied core based on the lithological characteristics

177 and total organic carbon (TOC) content. They appear as dark greenish and oily

178 layers, laminated or bioturbated depending on their thickness; homogenous, color-

179 banded or composite; with a TOC of at least 1\% [Murat and Got, 2000]. The studied

180 core has a continuous and undisturbed sedimentary record of sapropelic sequences

181 numbered from 1 for the youngest to 29 for the oldest according to the usual

182 standard.

$183 \quad 2-2$ Methodology

$184 \quad$ 2-2-1 Sampling strategy

185 Core scanner measurements were conducted on a slab collected at the surface of

186 the archive half core. The slabs were then regularly sampled to obtain isotopic data.

187 Geochemical analysis (TOC, $\mathrm{Ca}$ and $\mathrm{Br}$ ) and characterization of clay minerals were

188 performed on samples from the work half core. We considered 18 sapropelic

189 sequences of the available 28 (S1, S3, S5, S6, S7, S9, S10, S11, S12, S15, S17,

190 S19, S21, S23, S24, S27, S28 and S29) to obtain regular information through time

191 and conducted high-frequency sampling. "Sapropelic sequence" refers to a set of

192 samples collected below, inside and above the sapropel itself. Each sapropelic

193 sequence corresponds to a sedimentation period ranging from 10 to $20 \mathrm{ky}$. We

194 added a series of non-sapropelic samples deposited between 17 and 60 ka during

195 isotopic stages 2 to 4 .

196 To match the data obtained from the archive slab and work half core, lithologic

197 description was performed for both. The final lithologic synthesis was based on the 
198

199

200

201

202

203

204

205 fraction.

206 The isotopic composition of carbonate was measured according to the method

207 described in detail in Breitenbach and Bernasconi (2011). Briefly, approximately 60-

$20880 \mu \mathrm{g}$ of crushed, homogenized foraminifera shells were added to $4.5 \mathrm{ml}$ Exetainers,

209 (Labco, High Wycombe, UK) and flushed with pure helium. The samples were

210 reacted with 3-4 drops of $100 \%$ phosphoric acid at $70{ }^{\circ} \mathrm{C}$ with a Thermo Fisher

211 GasBench device connected to a Thermo Fisher Delta V mass spectrometer. The

212 average long-term reproducibility of the measurements based on replicated

213 standards was $\pm 0.06 \%$ for $\delta^{18} \mathrm{O}$. The instrument was calibrated with the international

214 standards NBS19 $\left(\delta^{18} \mathrm{O}=-2.2 \%\right)$ and NBS18 $\left(\delta^{18} \mathrm{O}=-23.01 \%\right)$. The isotope values

215 are reported in the conventional delta notation with respect to VPDB (Vienna Pee

216 Dee Belemnite).

217 The age model of MD04 2723 was established by correlation of the oxygen isotope

218 record with the Eastern Mediterranean G. ruber stack of Wang et al. (2010) using the

219 Software Analyseries (Paillard et al. 1996).

220

2-2-3 Total organic carbon 
221 The sediment samples were freeze-dried, crushed and homogenized for geochemical 222 analysis (total organic carbon, $\mathrm{Ca}$ and $\mathrm{Br}$ contents). For the analysis of total organic 223 carbon, sediment samples were acidified by $\mathrm{H}_{3} \mathrm{PO}_{4}(1 \mathrm{M})$ to remove carbonates, 224 dried on a hot plate at $40{ }^{\circ} \mathrm{C}$, and measured by combustion in a LECO CS 300 225 carbon sulfur analyzer. Two or three replicates of dried and homogenized sediment 226 (50 mg) were analyzed per sample.

\section{$227 \quad 2-2-4$ Rock-Eval pyrolysis}

228 All samples were analyzed with the Rock-Eval thermal analysis technique, using a 229 RE6 Turbo device (Vinci Technologies). Details of the RE6 apparatus are extensively 230 described in Behar et al. [2001]. Analyses were carried out using the operating 231 principles for the analysis of recent marine sediments. [Baudin et al., 2015]. The RE6 232 technique provided measurements from the sequential pyrolysis and oxidation of 233 approximately $40 \mathrm{mg}$ of desalted crushed sample. The pyrolysis gas effluents (mainly 234 hydrocarbons) were detected and quantified by flame ionization detection (FID), and 235 the evolution of $\mathrm{CO}$ and $\mathrm{CO}_{2}$ gas was quantified by infrared detection during the 236 pyrolysis and oxidation stages. The pyrolysis was carried out from $180^{\circ} \mathrm{C}$ to $650{ }^{\circ} \mathrm{C}$ 237 in an $\mathrm{N}_{2}$ atmosphere, whereas the oxidation was carried out from $300{ }^{\circ} \mathrm{C}$ to $850^{\circ} \mathrm{C}$ in 238 a laboratory air atmosphere.

239 The RE6 technique provides information on the quantity, type (sources) and thermal 240 evolution state of sedimentary organic matter.

$241 \quad 2-2-5$ Bromine and calcium analysis on single samples

242 The bromine and calcium contents were analyzed by X-ray fluorescence using an 243 xSORT instrument (Spectro Ametek). The instrument was set up on a stand, and 244 analyses were performed with the manufacturer's Environ-H program. Ground 
245 sediment was placed in a $15 \mathrm{~mm}$ diameter plastic cup with a $4 \mu \mathrm{m}$ thick

246 polypropylene window and was manually compacted. For each sample, four

247 replicates were analyzed during $300 \mathrm{~s}$.

248 For Ca, 25 eastern Mediterranean sediment samples analyzed by ICP-AES (Service 249 d'Analyses des Roches et Minéraux, SARM - Nancy). A range of concentrations from 2503 to $10 \%$ was used to calibrate the equipment. The detection limit was $50 \mathrm{ppm}$, and 251 the replicates agree within $5 \%$.

252 For $\mathrm{Br}$, we used standards prepared from a Mediterranean sediment for calibration. 253 The sediment was sieved with a mesh width of $40 \mu \mathrm{m}$ and high purity water, freeze254 dried, crushed and homogenized. Known quantities of $\mathrm{KBr}$ solution were added to 255 the sediment subsamples, and the subsamples were freeze-dried, crushed and 256 homogenized. The detection limit was 5 ppm, and the replicates agreed within 5\%.

257 The samples were also analyzed for calcium and total bromine (BrTot). Part of the 258 samples was then rinsed twice with ultrapure water to remove residual salt from 259 marine pore-water evaporation. A second analysis was carried out to analyze solid260 phase bromine (BrSol). Previous studies have shown that pure water removes $\mathrm{Br}$ 261 only to the extent that would be expected from dried interstitial water [Harvey, 1980;

262 Mayer et al., 1981; Mayer et al., 2007] and that insignificant organic bromine was 263 washed away [Mayer et al., 2007].

264 2-2-6 Bromine and calcium analysis by core scanner

265 High-resolution geochemical elemental composition records were measured directly 266 on the archive slab surface with an Avaatech XRF Core Scanner at the EPOC 267 Laboratory (University of Bordeaux). After cleaning and preparation of the slab 268 surface, three separate runs $(10,30$ and $50 \mathrm{kV}$, with currents of $0.6,1.5$ and $2.0 \mathrm{~mA}$, 
respectively) were performed every $5 \mathrm{~mm}$ down-core with a down-core slit size of 5 $\mathrm{mm}$. Sampling time was set to $10 \mathrm{~s}$ at $10 \mathrm{kV}, 15 \mathrm{~s}$ at $30 \mathrm{kV}$ and $20 \mathrm{~s}$ at $50 \mathrm{kV}$. The 271 slab surface was covered with a $4 \mu \mathrm{m}$ thin SPEXCerti Prep Ultralene1 foil to avoid 272 contamination of the XRF measurement unit and desiccation of the sediment. Raw 273 data spectra were processed by the analysis of the X-ray spectra using the iterative 274 least squares software (WIN AXIL) package from Canberra Eurisys. The elements 275 analyzed include a broad range, from aluminum ${ }^{13} \mathrm{Al}$ through uranium ${ }^{92} \mathrm{U}$ (Richter et 276 al, 2006, Tjallingii, 2007). In this paper, we focused on select elements, such as 277 calcium $(\mathrm{Ca})$ and total bromine (BrTot).

278 To transform core scanner relative data into quantitative results, 56 sediment 279 samples were selected within areas of the core scanner signal stability (at least 2 $280 \mathrm{~cm}$ ). Despite uncertainty linked to the variability of the water content, significant 281 correlations were highlighted between the core scanner data on wet sediment 282 samples and the X-ray fluorescence results on dried sediment samples (BrTot, $r=$ 283 0.95; Ca, $r=0.93)$.

$284 \quad 2-2-7$ Characterization of clay minerals

285 Sediments were gently crushed, and part of the collected powder (grain size less 286 than $50 \mu \mathrm{m}$ ) was added to deionized water to form mineral suspensions, which were 287 dispersed ultrasonically for 2 minutes. The less than $2 \mu \mathrm{m}$ fraction size of the 288 sediments was collected by sedimentation, and clay minerals were characterized 289 from the XRD patterns of the oriented preparations acquired in air-dried conditions 290 and after ethylene glycol solvation. XRD analyses were performed using a Bruker ${ }^{\circledR}$ 291 D8 XRD diffractometer (CuKa radiation). Diffracted beam CuKa ${ }^{1+2}$ radiation was used $292(40 \mathrm{kV}, 40 \mathrm{~mA})$ and collected by a linxeye detector. Relative humidity was not controlled during data acquisition. The oriented preparation of the less than $2 \mu \mathrm{m}$ 
294 fraction size was analyzed from $2^{\circ}$ to $30^{\circ} 2 \theta$ for a detailed characterization of the 295 d00 $\square$ reflections of phyllosilicates.

296 Petrographic studies were performed on the rock fragments using a JEOL 5600 LV 297 SEM equipped with an EDS (BRUKER XFlash 4030 Silicon drift detector). SEM 298 observations were performed in secondary electron imaging mode (SEI) for 299 morphological investigations and backscattering electron mode (BSE) on carbon300 coated thin sections for imaging of the chemical contrast and selection of local sites 301 for punctual chemical analysis. The analytical conditions were $15 \mathrm{kV}, 1 \mathrm{nA}$, a 302 counting time of $60 \mathrm{~s}$ and a working distance of $16.5 \mathrm{~mm}$. The standards used for 303 EDS consisted of albite ( $\mathrm{Na}, \mathrm{Al}, \mathrm{Si})$, almandine $(\mathrm{Mg}, \mathrm{Fe})$, diopside $(\mathrm{Ca})$, orthoclase $304(\mathrm{~K})$ and spessartite $(\mathrm{Mn})$. Matrix corrections were performed using an integrated 305 program (a PhiRhoz correction). The reproducibility of the standard analyses was 306 nearly $1.5 \%$ for all of the elements, except $\mathrm{Na}$, which had a reproducibility of $3 \%$.

307 TEM-EDX microanalyses were conducted on individual particles deposited on a C308 coated copper grid using a JEOL JEM 2011 TEM fitted with an X-Flash Silicon Drift 309 Detector 5030 (Bruker). The data collection parameters were set as follows: 310 magnification of $50000 \times, 4 \mathrm{~L}$ spot size, angular tilt of $20^{\circ}$ toward the detector, time 311 constant of $60 \mathrm{kcp} \cdot \mathrm{s}^{-1}$, energy range of $40 \mathrm{keV}$, and corrected counting time of $30 \mathrm{~s}$. 312 The beam diameter was set to $\sim 20 \mathrm{~nm}$ to reach the smallest particles.

313 The mid-infrared (MIR) spectra $\left(400\right.$ to $\left.4000 \mathrm{~cm}^{-1}\right)$ were acquired on $\mathrm{KBr}$ pellets 314 using a Nicolet 760 FTIR spectrometer equipped with a potassium bromide $(\mathrm{KBr})$ 315 beamsplitter and a DTGS-KBr detector. The resolution was set to $4 \mathrm{~cm}^{-1}$, with a co316 addition of 100 scans. $\mathrm{KBr}$ pellets contained $1 \mathrm{mg}$ of sample for every $150 \mathrm{mg}$ of $\mathrm{KBr}$ 317 powder, which was crushed into a mortar and pressed under 8 tons for 5 minutes in a 318 hydraulic press before drying at $120^{\circ} \mathrm{C}$. 
320 The relative amounts of kaolinite and smectite (smectite/kaolinite ratio) of the natural

321 samples were obtained from normalized near infrared spectra according to the

322 methodology described by Hébert et al. [2015]. Near-infrared spectra were collected

323 in reflectance mode using a Nicolet 750 FTIR spectrometer with an integration

324 sphere accessory. The spectrometer was equipped with a white light source, a $\mathrm{CaF}_{2}$

325 beam splitter and a PbSe detector. Spectra over the $10000-4000 \mathrm{~cm}^{-1}$ wavenumber

326 range were obtained by co-addition of 100 spectra with $4 \mathrm{~cm}^{-1}$ resolution. For

327 measurements, a few hundreds of milligrams of samples were either placed directly

328 onto the integration sphere's shutter or disposed into IR-transparent flasks when

329 unconsolidated.

330 Kaolinite and smectite have several atomic bonds within their crystal structure that 331 absorb radiation in the near-infrared domain. The absorption bands of kaolinite and 332 smectite can be observed in two regions of the infrared spectrum: from 1350 to 1500 $333 \mathrm{~nm}$ (for overtones of $\mathrm{OH}$ stretching vibrations) and from 2100 to $2400 \mathrm{~nm}$ (for the 334 combination of $\mathrm{OH}$ stretching and bending vibrations). The absorption bands of 335 kaolinite and smectite overlap in the two regions of interest. However, kaolinite has a 336 diagnostic absorption feature at $2165 \mathrm{~nm}$, and the relative proportions of smectite 337 and kaolinite can be determined by deconvolution of the four infrared (IR) bands that 338 are overlapped in the region between $2100 \mathrm{~nm}$ and $2300 \mathrm{~nm}$ (Hébert et al., 2015). 339 The smectite/smectite+kaolinite ratio calculated using this method corresponds to the 340 percentage of smectite in the clay material, which will be referred to as Sm\% 341 hereafter. 
343 Because each variable in the datasets used here can contain error [Laws and Archie,

344 1981; Sokal and Rohlf, 2012], we applied Model II regression to determine the

345 correlations between the studied variables. This model prevents underestimation of

346 the regression slope [Riker, 1973]. Regression analysis was performed using the

347 Imodel2 package from R language (R Development Core Team, 2013). The statistical

348 level of significance was defined at $p<0.05$ (Spearman's rank correlation test).

3493 Results

$350 \quad 3-1$ Sediment characteristics

351 The stratigraphic framework was established based on the $\delta^{18} \mathrm{O}$ isotopic record (Fig.

352 2). The core displays a complete record of the last $1080 \mathrm{ky}$. According to the very low

353 maximal burial depth reached by these sediments (the core length is only $36.5 \mathrm{~m}$ ),

354 physical parameters, such as temperature and pressure, did not significantly

355 influence the evolution of the studied parameters during the burial history.

356 Deposits are characterized by cyclic sedimentation of organic-rich sapropel layers 357 and organic-poor hemipelagic to pelagic sediments. Based on the sediment 358 thickness, and without considering the upper sediment column (0-6.5 m), which was

359 stretched by coring, the sedimentation rate varies slightly between $3.5 \mathrm{~cm} \mathrm{ky}^{-1}$ (6.5-

$36020.0 \mathrm{~m})$ and $2.8 \mathrm{~cm} \mathrm{ky}^{-1}(20.0-36.5 \mathrm{~m})$. The Ca concentration varies from 3.2 to

$36122.4 \%$, which corresponds to a carbonate content of 8 to $56 \%$ (Fig. 2). The upper

362 part of the core (0-493 ka) displays slightly higher values, with a mean of $11.9 \%$, than 363 the lower part (493-1084 ka), with a mean of 10.5\%. Thus, the Ca content exhibits a

364 weak but significant anticorrelation with age $(\mathrm{N}=7250, \mathrm{r}=-0.23)$. 
365 According to the discrete occurrence of sapropels in the sedimentary column, the 366 organic carbon content has high variability ( 0.17 to $6.74 \%$, S5 sequence for example) 367 on a small scale (10 to $20 \mathrm{ky}$ ) but is stable on a 1 my scale (Fig. 2). Correlation tests 368 prove that the TOC and age are independent variables $(\mathrm{N}=323, \mathrm{r}=-0.08)$. The 369 quantity of organic matter is constant through time.

370 Rock-Eval pyrolysis was originally developed to characterize the organic matter 371 present in oil source rocks [Espitalié et al., 1977], which are typically more thermally 372 mature and at higher concentrations than thermally immature marine sediments, like 373 the Mediterranean sapropels. Rock-Eval analyses have proved valuable in helping to 374 determine organic matter sources and the state of diagenetic transformation in 375 immature sediment samples [Bouloubassi et al., 1999; Baudin et al., 2007;

376 Tribovillard et al., 2008; Hatcher et al., 2014]. The hydrogen (HI) and oxygen indexes

377 (OI) are related to the atomic composition of the total organic matter and are 378 commonly plotted against each other in a modified van Krevelen-type plot (Fig. 3), in 379 which three main types of organic matter and their thermal alteration routes are 380 defined [Tissot and Welte, 1984].

381 The oxidation of organic matter affects both the $\mathrm{HI}$ and $\mathrm{OI}$. As marine organic matter 382 (Type II) is oxidized, there is a shift to lower $\mathrm{HI}$ and higher $\mathrm{Ol}$, and the $\mathrm{HI}-\mathrm{Ol}$ plot 383 approaches the characteristics of Type III vascular plant organic matter [Bouloubassi 384 et al., 1999 on the eastern Mediterranean ODP site 969]. The results of the Rock385 Eval analyses of sapropels from MD04 2723 exhibit a similar trend (Fig. 3). High 386 organic carbon sapropel samples correspond to marine Type II organic matter that is 387 well preserved and lower organic carbon to mainly altered marine organic matter. 388 Microbial alteration of the organic matter during sinking or in the upper sediment 389 layers, particularly by sulfate-reducing bacteria, has been reported to reduce the $\mathrm{HI}$ 
390 [Vetö et al., 1994]. The significant positive correlation between HI and TOC supports

391 this interpretation $(\mathrm{N}=20, \mathrm{r}=0.89)$.

392 3-2 Bromine

$393 \mathrm{BrTot}$ varies from 32 to $344 \mathrm{ppm}$, with a mean of $74 \mathrm{ppm}$ (Fig. 2). This variability

394 reflects the variation in the organic matter content; higher BrTot concentrations

395 correspond to sapropel layers. Statistical analysis of the dry sediment samples shows

396 a significant correlation ( $N=323, r=0.90)$ between $B r T o t$ and TOC. Despite this BrTot-

397 TOC correlation, a slight but significant evolution can be shown with the age

$398(\mathrm{~N}=7250, \mathrm{r}=-0.22)$. Without the sapropel layers, the anticorrelation is weaker

$399(\mathrm{~N}=6335, \mathrm{r}=-0.17)$. BrTot decreases through time, while TOC is constant.

400 To further explore this debromination, particular attention is paid to solid-phase

401 bromine (BrSol). BrSol and TOC display a highly significant relationship ( $\mathrm{N}=63$,

$402 \mathrm{r}=0.92)$ (Fig. 4 and Tab. 1).

403 The intercept of the all data regression lines tend towards zero. This proves that

$404 \mathrm{BrSol}$ is bromine linked to organic matter (BrOrg). This direct correlation between the

405 bromine content and the organic carbon content of marine sediments has been

406 demonstrated by several authors [Price et al., 1970; Price and Calvert, 1977;

407 Pedersen and Price, 1980; Martin et al., 1993; Ziegler et al., 2008; Leri et al., 2010].

408 The BrOrg results are in close proximity for low TOC contents and become more

409 scattered with increasing TOC. This dispersion can be explained by the age of the

410 samples. The more recent sapropelic sequences exhibit higher BrOrg than the older

411 ones at equivalent TOC concentrations. The analysis of this issue by sapropelic

412 sequences is presented in Table 1. 
413 The correlations are highly significant for the S1, S5, S17 and S28 sequences. The

414 numbers of samples are too low for the S9, S10 and S12 sequences; therefore, the

415 correlations are not statistically valid. Nevertheless, the different sequences display a

416 consistent trend of a decreasing slope with age (Fig. 5).

417 However, it remains to be determined whether the organic carbon content can affect 418 debromination. To highlight this possibility, we selected 4 data sets corresponding to 419 different TOC ranges and examined the evolution of BrOrg through time for each of 420 them (Fig. 6 and Tab. 2). We chose narrow ranges of TOC (0.5 to $0.8 \%$ ) and, when 421 possible, a broad range of ages.

422 Organic-poor samples (TOC $<0.5 \%$ ) do not show significant evolution through time $423(\mathrm{~N}=16, \mathrm{r}=-0.17, \mathrm{NS})$, i.e., our dataset does not allow us to demonstrate a change with 424 age. BrOrg is always low and remains almost constant.

425 In contrast, the $1.5-2.3 \%$ and $2.3-3 \%$ TOC ranges show significant linear correlations 426 of BrOrg with age, i.e., the higher the TOC range, the steeper slope, and the higher 427 correlation coefficient (Table 2).

428 The rate of debromination $(\mathrm{DBrR})$ increases with $\mathrm{TOC}$ content. For a mean $\mathrm{TOC}$ of $4290.24 \%$, BrOrg is almost stable (it varies from $<5$ to $12 \mathrm{ppm}$ during $1 \mathrm{my}$ ). $\mathrm{DBrR}$ 430 cannot be calculated, but is low. For a mean TOC of $1.83 \%$, BrOrg decreases from 43168 to $40 \mathrm{ppm}$ in $1 \mathrm{my}$, and $\mathrm{DBrR}=2.3 \times 10^{-4} \mu \mathrm{molBrOrg} \mathrm{molC}^{-1} \mathrm{y}^{-1}$. For a mean TOC 432 of $2.73 \%$, BrOrg decreases from 147 to $32 \mathrm{ppm}$ in $1 \mathrm{my}$, and DBrR increases to $6.3 \mathrm{x}$ $43310^{-4} \mu \mathrm{molBrOrg} \mathrm{molC}^{-1} \mathrm{y}^{-1}$.

434 For an organic carbon content greater than $4 \%$, the data are scarce. Only five 435 sapropel layers reach this level of TOC, and long periods of time are without data 436 (Fig. 2). Compared to the other ranges studied, the variability of BrOrg is greater for 
437 samples of similar TOC and age and outliers appear. The results obtained for the full

438 range (4.0-6.5\%) are comparable to those derived from the more limited ranges

$439(4.55-4.95 \%$ and 5.4-6.4\%). However, the slopes of the calculated regression lines

440 are lower than that for the $2.3-3 \%$ TOC range, approximately -0.07 . There is an

441 unexpected decrease in the rate of debromination to approximately $2.0 \times 10^{-4}$

$442 \mu \mathrm{molBrOrg} \mathrm{molC}^{-1} \mathrm{y}^{-1}$.

443 The intercepts provide an indication of the initial quantity of BrOrg, i.e., the quantity at

444 the time of deposit, so it is possible to calculate the initial value of BrOrg/TOC (Table

445 2). For the $<0.5 \%$ range, the initial BrOrg/TOC (weight ratio $29 \times 10^{-4}$, molar ratio 4.4

$446 \times 10^{-4}$ ) is in accordance with the value of the younger sample (weight ratio $30 \times 10^{-4}$,

447 molar ratio $4.5 \times 10^{-4}$, for $2 \mathrm{ka}$ ). Likewise, for the $1.5-2.3 \%$ range, the initial

$448 \mathrm{BrOrg} / \mathrm{TOC}$ (weight ratio $37 \times 10^{-4}$, molar ratio $5.6 \times 10^{-4}$ ) is in accordance with the

449 value of the younger sapropel $\left(\mathrm{N}=4\right.$, weight ratio $37.8 \times 10^{-4}$, molar ratio $5.7 \times 10^{-4}$ for

$4508 \mathrm{ka}$ ). For the higher TOC ranges, the youngest samples are too old for a valuable

451 comparison. For the $2.3-3.0 \%$ range, the initial calculated BrOrg/TOC is increasing

452 (weight ratio $54 \times 10^{-4}$, molar ratio $\left.8.1 \times 10^{-4}\right)$. However, for higher TOC $(4.0-6.5 \%$

453 range) the initial calculated BrOrg/TOC is decreasing (weight ratio $37 \times 10^{-4}$, molar

454 ratio $\left.5.6 \times 10^{-4}\right)$.

455 The solid-phase organic bromine-age relationship holds in the organic-rich

456 sediments, whereas it fails in the organic-poor sediments

457 3-3 Clay minerals

458 The bulk clay mineralogy of the organic-rich and organic-poor sediments is similar all

459 along the investigated core material. The XRD patterns obtained from the oriented

460 mounts of the less than $2 \mu \mathrm{m}$ fraction size of the sediments indicate that their clay 
461 material is primarily a mixture of smectite and kaolinite, with minor amounts of micas

462 [muscovite] and subordinated chlorite. Similar clay mineralogical composition has

463 been described on the Nile margin [Maldonado and Stanley, 1981; Stanley et al.,

464 1998; Hamann et al., 2009]. Smectite predominates in all samples. It was identified

465 from its broad $d_{001}$ reflection toward $15 \AA$ in the air-dried preparation of Ca-saturated

466 samples that expands to $17 \AA$ and the occurrence of a harmonic $\mathrm{d}_{002}$ reflection close

467 to $8.5 \AA$ after saturation with ethylene glycol (Fig. 7).

468 The large width at half maximum height $\left(\mathrm{FWMH}>1.5^{\circ} 2 \theta\right)$ of the $\mathrm{d}_{001}$ reflection and

469 the very low intensity of the $\mathrm{d}_{002}$ reflection of the smectite after ethylene glycol

470 saturation (which makes it difficult to identify in the XRD pattern) is indicative of the

471 low coherent scattering domain size (CSDS) of smectite crystallites. Kaolinite is

472 characterized by typical $d_{001}$ and $d_{002}$ reflections at $7.16 \AA$ and $3.57 \AA$, respectively.

473 From a comparative study of the XRD patterns of all samples, it can be observed that

474 the intensity ratio between the $d_{001}$ reflections of smectite and kaolinite significantly

475 varies all along the sapropelic sequence.

476 SEM observations indicate that very fine-grained clay particles (less than $2 \mu \mathrm{m}$ ) are

477 intimately mixed with calcareous micro- to nano-fossil oozes, particles of

478 carbonaceous material and very fine-grained detrital mineral, such as micas, alkali

479 feldspars and quartz. The authigenic minerals identified by petrographic observation

480 consist only of spherical aggregates of octahedral pyrite (framboidal pyrite), which is

481 very common within the organic-rich sediments (Fig. 8), and tiny crystals of

482 manganese oxides that have been observed locally in proximity to the sapropelic

483 horizons.

484 When observed after dispersion in water and sedimentation on a glass substratum

485 (Fig. 8b), the clay particles present a typical morphology of smectite (i.e., resulting in 
486 the aggregation of thin films of clay minerals with anhedral morphology) intimately

487 associated with more dispersed subhexagonal plates of kaolinite. HRTEM

488 observation of the smectite tactoids indicates that they are composed of very thin

489 crystallites, which display a very small number of stacked individual layers (less than

490 5) when oriented perpendicularly to $c^{*}$ (Fig. 8c). This is in agreement with the XRD

491 data, which indicated the low coherent scattering domain size (CSDS) of the smectite

492 crystallites.

493 The crystal-chemical characteristics of the smectite particles do not change

494 significantly along the investigated core. Despite a relatively large range of chemical

495 variation, which results from intimate mixing with different types of mineral impurities,

496 the punctual analyses obtained from SEM-EDX and TEM-EDX converge toward a

497 composition of montmorillonite (Table 3).

498 All structural formulas are characteristic of dioctahedral smectite with octahedral

499 occupancy ranging from 2 to 2.1 atoms per formula unit (a.p.f.u.), in which the

500 tetrahedral negative charge (due to substitution of Al with $\mathrm{Si}$ ) is very low (less than

501 0.2). Despite the uncertainty in the partitioning of $\mathrm{Mg}$ between the octahedral sheet

502 and interlayer position and the $\mathrm{Fe}^{2+} / \mathrm{Fe}^{3+}$ ratio within the octahedral sheet, the

503 negative charge of the 2:1 layer is due to $\mathrm{Mg}^{2+}$ for $\mathrm{Al}$ substitution. The

504 montmorillonitic composition of the smectite of both organic-rich and organic-poor

505 sediments is confirmed by the middle-infrared spectra of the clay material. The $\mathrm{OH}$

506 bending bands of the phyllosilicates between 820 and $915 \mathrm{~cm}^{-1}$ agree with the

507 dioctahedral nature of the clay minerals (kaolinite and smectite) contained in the

508 sample [Farmer, 1974]. Both kaolinite and smectite contributed to the $912 \mathrm{~cm}^{-1}$ band,

509 which was attributed to an AIAI-OH vibration. The 875 and $835 \mathrm{~cm}^{-1}$ absorption bands 
510 were attributed to $\mathrm{AlFe}^{3+}-\mathrm{OH}$ and $\mathrm{AlMg}^{2+}-\mathrm{OH}$ bending vibrations, respectively

511 [Farmer, 1974, Petit and Decarreau, 1990, Petit et al., 2002].

512 The quantitative analysis of the relative amounts of smectite and kaolinite in the bulk

513 samples by NIR spectrometry (Figure 9) confirms that smectite largely predominates

514 over kaolinite all along the investigated core.

515 The range of variation of the percentage of smectite in the clay material $(\mathrm{Sm} \%)$ is

516 restricted between 62 and 97\% (Fig. 2), and no clear variation can be observed in a

517 comparison of the $\mathrm{S} / \mathrm{K}$ ratios in the different compartments of the studied core. The

518 range of variation of the Sm\% determined at the scale of the sapropelic sequence is

519 often not far from that measured at the core-scale. The smectite content variability

520 cannot be linked to organic matter content variation, and TOC and Sm\% are two

521 relatively independent parameters $(\mathrm{N}=191, \mathrm{r}=-0.22$, highly significant). The most

522 significant variation of Sm\% observed at the core scale is an increase in the smectite-

523 rich samples (Sm\%>90) from the bottom (oldest sediments) to the top (younger

524 sediments) of the investigated core.

5254 Discussion

526 4-1 Debromination

527 There are many ways to explore debromination.

528 One way is BrTot high-frequency core scanner analysis (Fig. 2). Total bromine 529 consists of dissolved bromine and solid-phase bromine. The solid-phase bromine is 530 linked to organic matter and immobilized, but it progressively leaves the organic 531 matter and is released as bromide into pore water. Therefore, it decreases with age.

532 The dissolved bromine is composed of two components: (1) bromide provided by

533 marine pore-water salt at the time of deposition and debromination and (2) organic 
534 bromine. No significant chemical uptake processes are known to act as a sink for 535 bromide [Berg and Solomon, 2016]. Without the influence of other processes, BrTot 536 will remain constant. However, dissolved bromine is mobile. When debromination 537 occurs, the bromide concentration increases in the pore water more strongly in the 538 organic-rich layers than in the organic-poor layers. As a result, bromide is firstly 539 transported by diffusion from organic-rich to organic-poor sediment to equalize the 540 concentrations. On a larger timescale, bromide migrates through diffusion and/or 541 advection back toward the overlying ocean. The end result is that BrTot and its 542 variability range decrease with age, even though the bromide/chloride ratio increases 543 with depth [Berg and Solomon, 2016]. The MD04 2723 core scanner data exhibits 544 this general trend, whereas TOC remains constant at the same timescale, which 545 supports the debromination of the organic matter and the upward bromide migration.

546 However, BrTot and bromide/chloride ratio analysis provide a limited estimation of 547 debromination itself. Another way to obtain more accurate values is to compare $\mathrm{BrTot}$ 548 and the organic carbon content of organic-rich sediment layers. When TOC is high,

549 BrTot is mainly composed of bromine linked to organic matter and the pore-water 550 bromide can be neglected. The core MD04 2723 contains two highly organic-rich 551 sapropel layers: S5 and S28 (Fig. 2). They have similar maximum TOC contents $552(6.7 \%$ for S5 and $6.4 \%$ for S28) and different BrTot maximum concentrations (326 $553 \mathrm{ppm}$ for $\mathrm{S} 5$ and $174 \mathrm{ppm}$ for S28). The debromination rate can be estimated at $3.5 \mathrm{x}$ $55410^{-4} \mu$ molBrOrg molC ${ }^{-1} \mathrm{y}^{-1}$, in accordance with results obtained directly by the BrOrg 555 measurements (Tab. 2).

556 Studying BrOrg variability is a better way to obtain accurate values of the 557 debromination rates. There are two pathways acting simultaneously in biological 558 systems for the production of BrOrg, biotic production in cells of macro and 
559 microalgae as a result of the enzymatically mediated reaction of $\mathrm{Br}^{-}$and abiotic 560 production by nucleophilic substitution [Ballschmiter, 2003]. These reactions produce 561 aliphatic and aromatic forms of organobromine [Leri et al., 2014]. During organic 562 matter degradation, bromine can be removed from organobromine compounds 563 through microbial metabolic or abiotic debromination processes. One metabolic 564 pathway in the degradation of organic material is organohalide respiration. Bacteria 565 in anoxic environments utilize reductive dehalogenase to break the carbon-halogen 566 bond of organohalide compounds functioning as electron acceptors. The bromine is 567 replaced by a hydrogen atom. It has been hypothesized that this metabolic pathway 568 using reductive dehalogenase may be an important energy source for microbial 569 communities in the deep biosphere [Futagami et al., 2009]. The energy yield of 570 organohalide respiration in the natural environment can be several times greater, on 571 a per mole basis, than other metabolic pathways, such as sulfate reduction and 572 methanogenesis [Dolfing, 2003]. Bacterial groups that have the potential to use 573 organohalide respiration as a metabolic pathway have been found to be abundant in 574 deep subsurface marine sediments, both geographically and with depth [Futagami et 575 al., 2009; Orcutt et al., 2011]. Less is known about organohalide fermentation, but it 576 has been shown to be another potential energy-producing pathway for microbes in 577 the deep biosphere [Justicia-Leon et al., 2012; Lee et al., 2012]. Based on the BrOrg 578 concentration variability, we have demonstrated that the rates of debromination are 579 linked to the TOC contents. They increase from less than $2.3 \times 10^{-4} \mu \mathrm{molBrOrg} \mathrm{molC}^{-}$ $580{ }^{1} \mathrm{y}^{-1}$ up to $6.3 \times 10^{-4} \mu \mathrm{molBrOrg} \mathrm{molC}^{-1} \mathrm{y}^{-1}$ when TOC varies from 0.17 to $3 \%$. For 581 higher TOC values, precise rates of debromination could not be reliably established 582 due to scattered data (Fig. 6), but they decrease in all cases. To explore the 583 relationship between TOC and the rate of debromination, two assumptions are 
584 proposed: the rate of debromination depends on microbial activity and/or the

585 bioavailability of organic matter. Cragg et al. (1998) studied the bacterial

586 concentrations at the eastern Mediterranean ODP site 969, which has similar cyclic

587 sedimentation of organic-poor and organic-rich (80 sapropels beds to $116 \mathrm{mbsf}$ )

588 sediments. Within the range of TOC concentrations usually encountered in marine

589 sediments (0-3\%), the data set produced a significant correlation between TOC and

590 bacterial populations, in good agreement with the general profile derived from other

591 ODP sites. The addition of data with higher TOC destroyed the relationship, which

592 suggests that at high concentrations, such as those found in sapropels, TOC is

593 effectively present in excess and ceases to be a limiting factor for bacterial population

594 size. The remarkable fact that the bacterial populations and rates of debromination

595 both increase with the TOC concentration but only within the $0-3 \%$ range suggests

596 that debromination is quantitatively dependent on microbial activity. However, it is

597 difficult to explain why the TOC concentration does not behave as a limiting factor

598 when its content is greater than 3\%. Cragg et al. (1998) suggested that organic

599 carbon within the sapropel layers must be predominantly recalcitrant and only slowly

600 bioavailable.

601 The organic carbon content of the sapropel layers depends on the rate of

602 degradation/preservation of organic matter. During sapropelic periods, the water

603 column is stratified. The upper layer is normally oxygenated, and aerobic organic

604 matter degradation by microorganisms occurs. The lower layer is oxygen-depleted,

605 and organic matter is oxidized through various less-effective anaerobic pathways

606 [Demaison and Moore, 1980; Emerson and Hedges, 1988]. We assume that very

607 stable stratification results in a high-TOC sapropel (more than $3 \%$ ), and low organic

608 carbon sapropels correspond to instable stratification with periodic reoxygenation of 
609 the entire water column [Casford et al., 2003; Stefanelli et al., 2005 and Meyers et al.,

610 2006; Rohling et al., 2015]. The two degradation pathways produce different organic

611 molecules, which are less bioavailable in the case of oxygen-depleted conditions.

612 Therefore, in organic carbon-rich sapropels (TOC > 3\%) organic matter would not be

613 as bioavailable as in low organic carbon sapropels (TOC $<3 \%$ ). Furthermore, the

614 initial BrOrg/TOC also decreases at the 3\% TOC. The sediments with 2.3-3.0\% TOC

615 provide ideal conditions for the development of bacterial groups that may have the

616 potential to use organohalide respiration: a high content in $\mathrm{Br}$-rich organic matter.

617 Sediment with higher TOC has higher BrOrg content but a lower initial BrOrg/TOC

618 and could be less attractive.

619 However, some factors of the debromination rate variability for very high organic

620 carbon content remain to be identified. We need to explain why two samples

621 collected $3 \mathrm{~cm}$ apart within the same sapropel (S17) with the same TOC

622 concentration (4.7 and 4.8\%) present different BrOrg contents (140 and 86 ppm). The

623 first cited sample follows the general debromination trend, whereas the second

624 displays evidence of a higher rate (Fig. 6). Therefore, sometimes high rates of

625 debromination occur, even for high organic carbon content layers. The explanation of

626 this difference does not lie in the burial conditions, which are the same. Rather, the

627 solution is in the initial organic matter quality, which is dependent on the production

628 and/or degradation conditions. A $1 \mathrm{~cm}$ thick sample corresponds to three centuries of

629 basin history, a duration cannot analyze the climatic variability of the temperature

630 sea-surface, Nile floods or depth of the oxic/anoxic water interface, three parameters

631 that may have influenced the quality of the produced and preserved organic matter

632 [Meyers, 2006]. Sapropels are organic-rich layers, but for most of them, preserved

633 organic matter represents a small portion of the produced organic matter. For low 
634 TOC content sapropels (1-3\%), the initially produced marine organic matter is mainly

635 degraded. Thus, the degradation step plays a major role in the quality of the finally

636 preserved organic matter. In contrast, for higher organic carbon sapropels, even if the

637 degradation pathways remain important, a higher proportion of produced organic

638 matter is preserved and the quality of the produced organic matter is a more

639 important factor in the variability of bioavailability.

$640 \quad 4-2$ Clay mineral evolution

641 The core MD04 2723 provides an opportunity to examine the evolution of layer

642 silicates in parallel to that of organic matter during the last million years of

643 sedimentation and eogenesis of sediments in the eastern part of the Egyptian

644 continental margin. Kaolinite and smectite are known to be the diagnostic clay

645 minerals of the eogenesis of mudstones (Burley, 1993 and references therein).

646 However, it is unclear whether these clay minerals originate from sedimentation

647 (detrital clays) and/or from the eogenesis of the sediments during their incipient

648 burial.

649 This study shows that (1) there is no evidence of authigenic clay minerals and that (2)

650 dioctahedral smectite largely predominates over kaolinite in the samples collected all

651 along the core MD04 2723. More specifically, infrared spectroscopy and

652 microchemical analyses indicated that the crystal chemistry of the dioctahedral

653 smectite agrees with that of montmorillonite. Its mineralogical and chemical

654 composition is similar to that of the smectite previously identified in the Nile

655 suspended matter [Dekov et al., 1997] and the Nile alluvial soils in Egypt [Kishk et al.,

656 1976] and the range of Sm\% measured all along the core is in full agreement with the

657 published clay mineral data from the Nile assemblage [Hamann et al., 2009]. On the

658 basis of the qualitative analysis in this study, it is assumed that the clay mineralogy of 
659 the core MD04 2723 is essentially representative of the detrital Nile source. However, 660 on the basis of quantitative analysis, Sm\% variability is likely to occur at two different 661 timescales.

662 Some sapropelic sequences exhibit a wide range of variation in Sm\% (S10, for 663 example, $71-97 \%$, Fig. 2) while others do not (S15, for example, 66-73\%, Fig. 2). The 664 highest Sm\% can be located either in the organic-rich (S10 and S11 sequences) or in 665 the organic-poor (S7 and S9 sequences) sequences. The controlling factor of the $666 \mathrm{Sm} \%$ variation is not climatic because all four aforementioned sapropels correspond

667 to low values of the $\delta^{18} \mathrm{O}$ isotopic record. As expected from the absence of diagenetic 668 evolution of clay minerals, the smectite concentration and TOC are not correlated.

669 Over a span of one million years, a slight change occurs, which is highlighted by the 670 mean values for each sapropelic sequence (Fig. 10).

671 The lower part of the core ( 500 to $1080 \mathrm{ka}$ ) is characterized by a nearly constant and 672 low (69-73\%) Sm\%, whereas the upper part is characterized by heterogeneous mean 673 values with successively increasing or decreasing gradients (Sm\% between 71 and $67488 \%$ ), which cannot be linked to the $\delta^{18} \mathrm{O}$ isotopic record. The 500 ka limit also

675 affects others sedimentary parameters, such as the Ca concentration and 676 sedimentation rate. The last 500 ky shows an increase in the sedimentation rate, the 677 carbonate content and the Sm\% variability. Even though the cause of these 678 variations remains uncertain, the hypothesis of temporal change in detrital sources 679 can be invoked.

6805 Conclusion

681 The studied site displays both a high degree of stability in the organic supply at a 682 one-million-year scale and great variability in the organic matter preservation at a 10 
683 ky scale, an ideal situation to highlight and discuss the influence of the organic matter

684 content on the mineralogical and geochemical evolution during eogenesis. This

685 allows us to demonstrate that at a one-million-year scale, the organic matter content

686 has no significant influence on clay eogenesis. Detrital smectite and kaolinite remain

687 unchanged everywhere, even within the sapropels where high bacterial populations

688 are active.

689 We have demonstrated that solid-phase BrOrg is a reliable tracer of debromination

690 rates in marine sediments. Based on the highly variable TOC concentration of the

691 eastern Mediterranean sea, it was determined that the rates of debromination

692 depend on the organic matter content. This observation provides the basis for further

693 investigation of other oceanic basins. Within the range of TOC concentrations usually

694 encountered in marine sediments $(0-3 \%)$, both bacterial populations and the rates of

695 debromination increase with TOC content. It can be assumed that these two

696 parameters are correlated. The increase in bioavailable organic matter induces

697 growth of active bacterial populations, resulting in higher rates of debromination. In

698 the eastern Mediterranean sea, the depth profile of the bacterial populations is in

699 good agreement with the general profile derived from other oceans [Cragg et al.,

700 1998; Parkes et al., 2014]. This suggests that the rates of debromination obtained in

701 the Mediterranean sea are relevant for all ocean basins. This assumption should be

702 supported by further investigations, which could be performed on a basin that

703 displays a high and stable organic carbon content over time. This approach would

704 provide only one rate of debromination. It would be more interesting to search for a

705 Mediterranean-like basin that exhibits both a high degree of stability of the organic

706 supply at a one-million-year scale and great variability in the organic matter content

707 at a $10 \mathrm{ky}$ scale. Different rates of debromination could be investigated. Extending 
708 the time-range of the sedimentation and diagenetic evolution to a ten-million-year

709 scale would show whether clay minerals remain stable over a one-million-year scale 710 due to of slow reaction kinetics.

712 Acknowledgements

713 This work was funded by the French program "Action Marges". We thank Jean

714 Mascle and the on-board scientific team for their assistance and Yvon Balut and the

715 Marion Dufresne II crew (French Polar Institute: IPEV) for technical support during 716 the Vanil cruise.

717

718 References:

719 ARNDT S., JøRGENSEN B.B., LAROWE D.E., MIDDELBURG J.J., PANCOST R.D.

720 \& REGNIER P. (2013). - Quantifying the degradation of organic matter in marine

721 sediments: A review and synthesis. - Earth-Science Reviews, 123, 53-86

722 BALLSCHMITER K. (2003). - Pattern and sources of naturally produced

723 organohalogens in the environment: biogenic formation of organohalogens. -

724 Chemosphere, 52, 313-324.

725 BARNES M. A., BARNES W.C. \& BUSTIN R. M. (1990). - Chemistry and diagenesis

726 of organic matter in sediments and fossil fuels. In: Geoscience Canada Reprint

727 Series, Diagenesis, 189-204.

728 BAUDIN F., COMBOURIEU-NEBOUT N. \& ZAHN R. (2007). - Signatures of rapid

729 climatic changes in organic matter records in the western Mediterranean Sea during

730 the last glacial period. - Bull. Soc. Géol. Fr., 178, 1, 3-13. 
731 BAUDIN F., DISNAR J.P., ABOUSSOU A. \& SAVIGNAC F. (2015). - Guidelines for

732 Rock-Eval analysis of recent marine sediments. - Org. Geochem., 86, 71-80.

733 BEHAR F., BEAUMONT V. \& DE PENTEADO, H.L. (2001). - Rock-Eval 6

734 technology: performances and developments. - Oil and Gas Science and

735 Technology, 56, 111-134.

736 BERG R.D. \& SOLOMON E.A. (2016). - Geochemical constraints on the distribution

737 and rates of debromination in the deep subseafloor biosphere. - Geochim.

738 Cosmochim. Acta, 174, 30-41.

739 BÉTHOUX J.P. \& PIERRE C., (1999). - Mediterranean functioning and sapropel

740 formation: respective influences of climate and hydrological changes in the Atlantic

741 and the Mediterranean. - Mar. Geol., 153, 29-39.

742 BOULOUBASSI I., RULLKÖTTER J. \& MEYERS, P.A. (1999). - Origin and

743 transformation of organic matter in Pliocene-Pleistocene Mediterranean sapropels:

744 organic geochemical evidence reviewed. - Mar. Geol., 153, 177-197.

745 BREITENBACH S.F.M. \& BERNASCONI S.M. (2011). - Carbon and oxygen isotope 746 analysis of small carbonate samples (20 to $100 \mu \mathrm{g})$ with a GasBench II preparation

747 device. - Rapid Communications in Mass Spectrometry, 25, 1910-1914.

748 BURLEY S. D. (1993). - Models of burial diagenesis for deep exploration plays in

749 jurassic fault traps of the central and Northern North Sea. - Geological Society,

750 London, Petroleum Geology Conference series 1993, 4, 1353-1375.

751 CASFORD J.S.L., ROHLING E.J., ABU-ZIED R.H., JORISSEN F.J., LENG M. \&

752 THOMSON J. (2003). A dynamic concept for eastern Mediterranean circulation and 
753 oxygenation during sapropel formation. - Palaeogeogr. Palaeoclimatol. Palaeoecol., $754190,103-119$.

755 COLEMAN M. L. (1985). - Geochemistry of non silicate minerals: kinetic

756 considerations. - Philosophical Transaction of the Royal Society of London, 315, 39-

75756.

758 CRAGG B. A., LAW K.M., CRAMP A, \& PARKES R.J. (1998). - The response of

759 bacterial populations to sapropels in deep sediments of the Eastern Mediterranean

760 (site 969). - In: A.H.F Robertson, K.-C. Emeis, C. Richter, \& A. Camerlenghi Eds.,

761 Proceedings of the Ocean Drilling Program, Scientific Results, Vol. 160, Texas A\&M

762 University, College Station, TX, 303-307.

763 CRAMP A. \& O'SULLIVAN G. (1999). - Neogene sapropels in the Mediterranean: a

764 review. - Mar. Geol., 153, 11-28.

765 DEKOV V.M., KOMY Z., ARAUJO F., VAN PUT A. \& VAN GRIEKEN R. (1997). -

766 Chemical composition of sediments, suspended matter, river water and ground water

767 of the Nile (Aswan-Sohag traverse). - The science of the total environment, 201,

$768 \quad 195-210$.

769 DEMAISON G.J. \& MOORE G.T. (1980). - Anoxic environments and oil bed genesis.

770 -Am. Assoc. Pet. Geol. Bull., 64, 1179-1209.

771 DOLFING J. (2003). - Thermodynamic Considerations for Dehalogenation. - In: M.

772 M. Häggblom, I. D. Bossert Eds, Dehalogenation: Microbial Processes and

773 Environmental Applications. Springer, 89-114.

774 DUCASSOU E., CAPOTONDI L., MURAT A., BERNASCONI S., MULDER T.,

775 GONTHIER E., MIGEON S., DUPRAT J., GIRAUDEAU J. \& MASCLE J. (2007). - 
776 Multiproxy late quaternary stratigraphy of the Nile deep-sea turbidite system -

777 Towards a chronology of deep-sea terrigeneous systems. - Sedimentary Geology,

$778200,1-13$.

779 EMEIS K.C., SAKAMOTO T., WEHAUSEN R. \& BRUMSACK H.J. (2000). - The 780 sapropel record of the eastern Mediterranean Sea - results of Ocean Drilling 781 Program Leg 160. - Palaeogeogr. Palaeoclimatol. Palaeoecol. 158, 371-395.

782 EMERSON S. \& HEDGES J.I. (1988). - Processes controlling the organic carbon 783 content of open ocean sediments. Paleoceanography, 3, 621-634.

784 ESPITALIE J., LAPORTE J.L., MADEC M., MARQUIS F., LEPLAT P., PAULET J. \& 785 BOUTEFEU A. (1977). - Méthode rapide de caractérisation des roches mères, de 786 leur potentiel pétrolier et de leur degré d'évolution. - Rev. Inst. Fr. Pét., 32, 23-42.

787 FARMER V.C. (1974). - The Infrared Spectra of Minerals. - Monograph, 4. The 788 Mineralogical Society, London, 539 p.

789 FUTAGAMI T., MORONO Y., TERADA T., KAKSONEN A. H. \& INAGAKI F. (2009). -

790 Dehalogenation activities and distribution of reductive dehalogenase homologous 791 genes in marine subsurface sediments. - Appl. Environ. Microbiol., 75, 6905-6909.

792 GIESKES J.M. \& MAHN C. (2007). - Halide systematics in interstitial waters of ocean 793 drilling sediment cores. - Applied Geochemistry, 22, 515-533.

794 GRIBBLE G.W. (2003). - The diversity of naturally produced organohalogens.

795 Chemosphere, 52, 289-297.

796 HAMANN, Y., EHRMANN, W., SCHMIEDL, G., \& KUHNT, T. (2009). - Modern and 797 late Quaternary clay mineral distribution in the area of the SE Mediterranean Sea. 798 Quaternary Research, 71, 453-464. 
HATCHER, P., RAVIN, A., BEHAR, F., BAUDIN, F. (2014). - Diagenesis of organic

800 matter in a $400 \mathrm{~m}$ organic rich sediment core from offshore Namibia using solid state

801 13C NMR and FTIR. - Org. Geochem., 75, 8-23.

802 HARVEY G.R. (1980). - A study of the chemistry of iodine and bromine in

803 marine sediments. - Mar. Chem., 8, 327-332.

804 HASSAN F.A. (1981). - Historical Nile floods and their implications for climatic 805 change. - Science, 212, 5, 1142-1144.

806 HATCHER P., RAVIN A., BEHAR F. \& BAUDIN F. (2014). - Diagenesis of organic 807 matter in a $400 \mathrm{~m}$ organic rich sediment core from offshore Namibia using solid state 808 13C NMR and FTIR. - Org. Geochem., 75, 8-23.

809 HÉBERT B., BEAUFORT D., ROY R., POURADIER A. \& JIKIBAYEV R. (2015) -

810 New methods to quantify clay minerals in the uranium deposits hosted in sands of the

811 Chu Sarysu Basin (South Kazakhstan) based on visible and near-infrared field

812 spectrometry. In: Proc. 13th Biennial SGA Meeting. - Nancy, France, 587-589.

813 JORISSEN F.J. (1999). - Benthic foraminiferal successions across Late Quaternary

814 Mediterraenan sapropels. - Mar. Geol., 153, 91-101.

815 JUSTICIA-LEON S. D., RITALAHTI K. M., MACK E. E. \& LÖFFLER F. E. (2012). -

816 Dichloromethane fermentation by a Dehalobacter $\mathrm{sp}$. in an enrichment culture

817 derived from Pristine river sediment. - Appl. Environ. Microbiol., 78, 1288-1291.

818 KALLEL N., DUPLESSY J.-C., LABEYRIE L., FONTUGNE M., PATERNE M. \&

819 MONTACER, M. (2000). - Mediterranean pluvial periods and sapropel formation over 820 the last 200000 years. - Palaeogeogr. Palaeoclimatol. Palaeoecol., 157, 45-58. 
821 KISHK F.M., EL-ATTAR H.A., HASSAN M.N. \& EL-SHEEMY H. (1976). -

822 Mineralogical and chemical composition of the clay fraction of some Nile alluvial soils

823 in Egypt. - Chem. Geol., 17, 295-305.

824 KROON D., ALEXANDER I., LITTLE, M., LOURENS L.J., MATTHEWSON A., 825 ROBERSTON A.H.F. \& SAKAMOTO T. (1998). - Oxygen isotope and sapropel 826 stratigraphy in the eastern Mediterranean during the last 3.2 million years. - In:

827 Proceedings of the Ocean Drilling Program, Scientific Results, Leg 160, 181-189.

828 LAWS E.A. \& ARCHIE J.W. (1981). - Appropriate use of regression analysis in 829 marine biology. - Mar.Biol., 65,13-16.

830 LEE M., LOW A., ZEMB O., KOENIG J., MICHAELSEN A. \& MANEFIELD M. (2012).

831 - Complete chloroform dechlorination by organochlorine respiration and fermentation. 832 - Environ. Microbiol., 14, 883-894.

833 LERI A. C., HAKALA J. A., MARCUS M. A., LANZIROTTI A., REDDY C.M. \& 834 MYNENI S. C. B. (2010). - Natural organobromine in marine sediments: new 835 evidence of biogeochemical Br cycling. - Global Biogeochem. Cycles, 24, GB4017.

836 LERI A.C., MAYER L.M., THORNTON K.R. \& RAVEL B. (2014). - Bromination of 837 marine particulate organic matter through oxidative mechanisms. - Geochim.

838 Cosmochim. Acta, 142, 53-63.

839 MC KINLEY J.M., WORDEN R.H. \& RUFFELL A.H. (2003). Smectites in

840 Sandstones: a review of the controls on occurrence and behaviour during diagenesis.

841 In: R.H. Worden \& S. Morad (Eds.), Clay mineral cements in Sandstones. Blackwell 842 Publishing, 109-128.

843 MAHN, C. L. \& J. M. GIESKES (2001). - Halide systematics in comparison 
844 with nutrient distributions in sites 1033B and 1034B, Saanich Inlet: ODP

845 Leg 169S. - Mar. Geol., 174, 1-4, 323-339.

846 MALDONADO A. \& STANLEY D. J. (1981). - Clay mineral distribution patterns as

847 influenced by depositional processes in Southeastern Levantine Sea. -

848 Sedimentology, 28, 21-32.

849 MARTIN J. B., GIESKES J. M., TORRES M. \& KASTNER M. (1993). - Bromine and

850 iodine in Peru margin sediments and pore fluids: implications for fluid origins.

851 Geochim. Cosmochim. Acta, 57, 4377-4389.

852 MAYER L.M., MACKO S.A., MOOK W.H. \& MURRAY S.M. (1981). - The distribution 853 of bromine in coastal sediments and its use as a source indicator for organic matter. -

854 Org. Geochem., 3, 37-42.

855 MAYER L.M. (1994). - Surface area control of organic carbon accumulation in 856 continental shelf sediments. - Geochim. Cosmochim. Acta, 58, 1271-1284.

857 MAYER L.M., SCHICK L.L., ALLISON M., RUTTENBERG K. \& BENTLEY S. (2007). 858 - Marine vs. terrigenous organic matter in Louisiana coastal sediments: the uses of 859 Bromine: organic carbon ratios. - Mar. Chem., 107, 244-254.

860 MEYERS P.A. (2006). - Paleoceanographic and paleoclimatic similarities between

861 Mediterranean sapropels and Cretaceous black shales. - Palaeogeogr.

862 Palaeoclimatol. Palaeoecol., 235, 305-320.

863 MIDDELBURG J.J. (1989). - A simple rate model for organic-matter decomposition in 864 marine-sediments. - Geochim. Cosmochim. Acta, 53, 1577-1581. 
865 MURAT A. \& GOT H. (2000). - Organic carbon variations of the eastern

866 Mediterranean Holocene sapropel: a key for understanding formation processes. -

867 Palaeogeogr. Palaeoclimatol. Palaeoecol., 158, 241-257.

868 OLAUSSON E. (1961). - Studies of deep-sea cores. - Reports of the Swedish Deep 869 Sea Expedition 1947-1948, 8, 353-391.

870 ORCUTT B. N., SYLVAN J. B., KNAB N. J. \& EDWARDS K. J. (2011). - Microbial

871 ecology of the dark ocean above, at, and below the seafloor. - Microbiol. Mol. Biol.

872 Rev., 75, 361-422.

873 PAILLARD D., LABEYRIE L. \& YIOU P. (1996). - Macintosh Program performs time-

874 series analysis. - Eos, Trans. Am. Geophys.Union, 77, 39, 379-379.

875 PARKES R.J., CRAGG B., ROUSSEL E., WEBSTER G., WEIGHTMAN A. \& SASS

876 H. (2014). - A review of prokaryotic populations and processes in sub-seafloor

877 sediments, including biosphere: geosphere interactions. - Mar. Geol., 352, 409-425.

878 PEDERSEN T. \& PRICE N. (1980). - The geochemistry of iodine and bromine in

879 sediments of the Panama Basin. - J. Mar. Res., 38, 397-411.

880 PETIT S., CAILLAUD J., RIGHI, D. \& MADEJOVÁ J. (2002). - Characterization and 881 crystal chemistry of an Fer-rich montmorillonite from Ölberg, Germany. - Clay 882 Minerals, 37, 2, 283-297.

883 PETIT S. \& DECARREAU A. (1990). - Hydrothermal (200 degrees C) synthesis and 884 crystal chemistry of iron-rich kaolinites. - Clay Minerals, 25, 2, 141-160.

885 PRICE N. B., CALVERT S. E. \& JONES P. G. W. (1970). - The distribution of iodine 886 and bromine in the sediments of the South Western Barents Sea. - Mar. Res., 28, 2288734. 
888 PRICE N. B. \& CALVERT S. (1977). - The contrasting geochemical behaviours of 889 iodine and bromine in recent sediments from the Namibian shelf. - Geochim. 890 Cosmochim. Acta, 41, 1769-1775.

891 PRYOR W. A. (1975). - Biogenic sedimentation and alternation of argillaceous 892 sediments in shallow marine environments. - Geological Society of America Bulletin, $89386,1244-1254$.

894 R DEVELOPMENT CORE TEAM. (2013). - R: a Language and Environment for 895 Statistical Computing. 3-900051-07-0 R Foundation for Statistical Computing, 896 Vienna, Austria, URL 〈http://www.R-project.org/).

897 RICHTER T.O., VAN DER GAAST S., KOSTER B., VAARS A., GIELES R., DE 898 STIGTER H.C., DE HAAS H. \& VAN WEERING T.C.E. (2006). - The Avaatech XRF 899 Core Scanner: technical description and applications to NE Atlantic sediments. 900 Geological Society London, Special Publication, 267, 39-50.

901 RICKER W.E. (1973). - Linear regressions in fishery research. - J. De. l'Off. Des. 902 Rech. sur Les. Pêcheries Du. Can., 30, 3,409-434.

903 ROHLING E.J. (1994). - Review and new aspects concerning the formation of 904 Mediterranean sapropels. - Mar. Geol., 122, 1-28.

905 ROHLING E.J., MARINOA G. \& GRANT K.M. (2015). - Mediterranean climate and 906 oceanography, and the periodic development of anoxic events (sapropels). - Earth907 Science Reviews, 143, 62-97.

908 ROSSIGNOL-STRICK M. (1985). - Mediterranean Quaternary sapropels, an 909 immediate response of the African monsoon to variations of insolation. 910 Palaeogeogr. Palaeoclimatol. Palaeoecol., 49, 237-263. 
911 SCHILMAN B., ALMOGI-LABIN A., BAR-MATTHEWS M., LABEYRIE, L., PETERNE

912 M. \& LUZ, B. (2001). - Long- and short-term carbon fluctuations in the eastern

913 Mediterranean during the late Holocene. - Geology, 29, 12, 1099-1102.

914 SOKAL R.R. \& ROHLF F.J. (2012). - Biometry: The Principles and Practice of 915 Statistics. - in: W. H. Freeman and Co Eds, Biological Research, 4th edition., New 916 York, 937p.

917 STANLEY, D. J., NIR, Y., \& GALILI, E. (1998). - Clay mineral distributions to interpret

918 Nile cell provenance and dispersal: III. Offshore margin between Nile delta and

919 northern Israel. - Journal of coastal Research, 14, 196-217.

920 STEFANELLI S., CAPOTONDI L. \& CIARANFI N. (2005). - Foraminiferal record and

921 environmental changes during the deposition of the Early-Middle Pleistocene

922 sapropels in southern Italy. - Palaeogeogr. Palaeoclimatol. Palaeoecol., 216, $27-52$.

923 SURDAM R. C., DUNN T. L., HEATHER H.P. \& MACGOWAN, D.B. (1989). -

924 Integrated diagenetic modelling; a process orientated approach for clastic systems.

925 Annual Reviews of Earth and Planetary Science Letters, 15, 141-170.

926 TENHAVEN H. L., DELEEUW J. W., SCHENCK P. A. \& KLAVER G. T. (1988). -

927 Geochemistry of Mediterranean sediments—Bromine/organic carbon and

928 uranium/organic carbon ratios as indicators for different sources of input

929 and post-depositional oxidation, respectively. - Org. Geochem., 13, 1-3,

$930 \quad 255-261$. 
931 TJALLINGII R., RÖHL U., KÖLLING M. \& BICKERT T. (2007). - Influence of the 932 water content on X-ray fluorescence core-scanning measurements in soft marine 933 sediments. - Geochem. Geophys. Geosyst., 8, Q02004.

934 TISSOT B.P. \& WELTE D.H. (1984). - Petroleum Formation and Occurrence. -

935 2nd. ed. Springer, Heidelberg, 601 p.

936 TRIBOVILLARD N., BOUT-ROUMAZEILLES V., SIONNEAU T., MONTERO-

937 SERRANO J.C., RIBOULLEAU A. \& BAUDIN F. (2009). - Organic-matter

938 preservation and accumulation in an anoxic setting: the Orca Basin, Gulf of Mexico.

939 Comptes Rendus Geosciences, 341, 1-9.

940 UPSTILL-GODDARD R. C. \& ELDERFIELD H. (1988). - The role of diagenesis in the 941 estuarine budgets of iodine and bromine. - Cont. Shelf Res., 8, 405-430.

942 VETÖ I., HETÉNYI M., DEMÉNY A. \& HERTELENDI E. (1994). - Hydrogen index as 943 reflecting intensity of sulphidic diagenesis in non-bioturbated, shaly sediments. - Org. 944 Geochem., 22, 299-310.

945 WANG P. X., TIAN J. \& LOURENS L. J. (2010). - Obscuring of long eccentricity 946 cyclicity in Pleistocene oceanic carbon isotope records. - Earth and Planetary 947 Science Letters, 290, 3-4, 319-330.

948 WORDEN R.H. \& BURLEY S.D. (2003). - Sandstone diagenesis: the evolution from 949 sand to stone. - In: S.D. Burley \& R.H. Worden (Eds.), Clastic Diagenesis: Recent 950 and Ancient, International Association of Sedimentologists, 4, 3-44.

951 WORDEN R. H. \& MORAD S. (2003). - Clay minerals in sandstones: controls on 952 formation, distribution and evolution. - In: R.H. Worden \& S. Morad (Eds.), Clay 953 mineral cements in Sandstones. Blackwell Publishing, 3-41. 
954 ZIEGLER M., JILBERT T., DE LANGE G. J., LOURENS L. J. \& REICHART G.-J.

955 (2008). - Bromine counts from XRF scanning as an estimate of the marine organic 956 carbon content of sediment cores. - G-cubed, 9, Q05009. 
Figure captions

959 Figure 1: Morphobathymetric map of the Nile margin and location of the studied core 960 MD04 2723.

961 Figure 2: Core MD04 2723 data evolution with age: lithology, isotopic stratigraphy, 962 Marine Isotopic Stages (MIS), Ca, BrTot, TOC and Sm\%.

963 Figure 3: Modified van Krevelen diagram showing the sapropel results $(\mathrm{N}=20)$ with 964 indications of the sapropel number and TOC content in \%.

965 Figure 4: The relationship between TOC and solid-phase bromine. Bromine data 966 values below the detection limit (5 ppm) were nullifying. Black dots: S5 sequence, 967 Black squares: S28 sequence, Black dash: other sequences.

968 Figure 5: Evolution of the BrOrg/TOC ratio with age by sapropelic sequence.

969 Time is obviously a factor in BrOrg variability. The evolution of the slope (or ratio of 970 BrOrg to TOC) with age indicates a loss of BrOrg of approximately $50 \%$ in 1.1 million 971 years.

972 Figure 6: Evolution of BrOrg with age by TOC range. Red crosses: $<0.5 \%$, purple 973 dots: $1.5-2.3 \%$, blue triangles: $2.3-3 \%$ and green squares: $4.0-6.5 \%$.

974 Figure 7: XRD patterns of the clay material extracted from sample MD04 2723-1-

975 48. Diffractograms of the oriented preparations of the less than $2 \mu \mathrm{m}$ fraction size

976 acquired in air-dried conditions (A.D.) and after saturation with ethylene glycol. 977

978 Figure 8: Aspect of the smectitic material in the middle part of the S5 sapropelic 979 horizon (section 6, 22.5-23.5 cm): (a) SEM observation, an intimate mixture of clay 980 and carbonaceous particles in the bulk material; (b) flakes of smectite particles 
981 deposited onto a glass slide; (c) HRTEM image of the individual crystallites of the 982 smectite tactoids.

983

984 Figure 9: Decomposition of the near-infrared spectra of samples in which the clay 985 material is composed of (a) 75\% smectite-25\% kaolinite and (b) $90 \%$ smectite-10\% 986 kaolinite. See Herbert et al., 2015 for more details on the method of quantification of $987 \mathrm{Sm} \%$.

988 Figure 10: Main results through time, solid-phase organic bromine evolution as a 989 function of the TOC range (each straight line corresponds to a different 990 debromination rate), and relative stability of the detrital montmorillonite supply. 991 


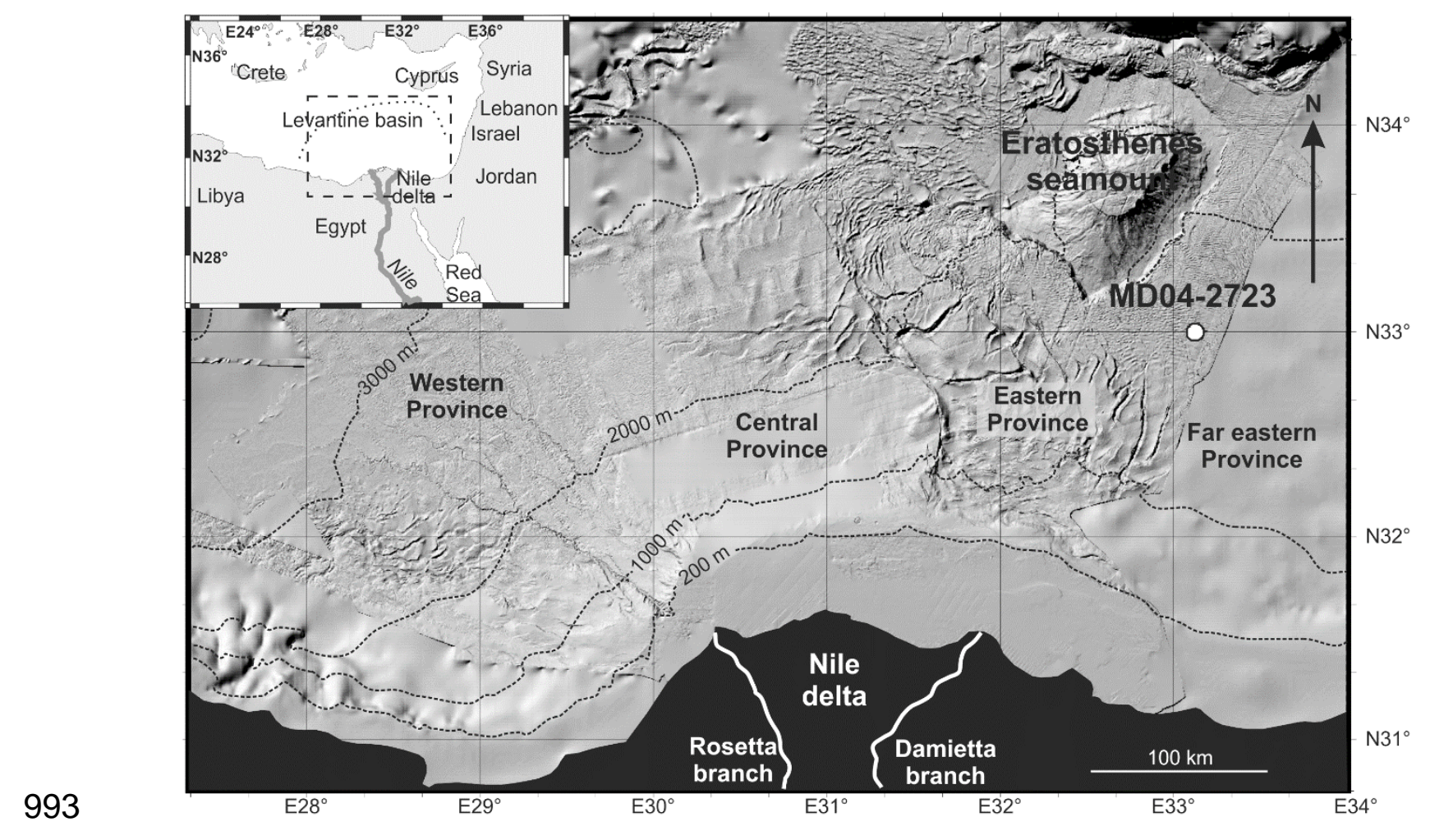

994 Figure 1 


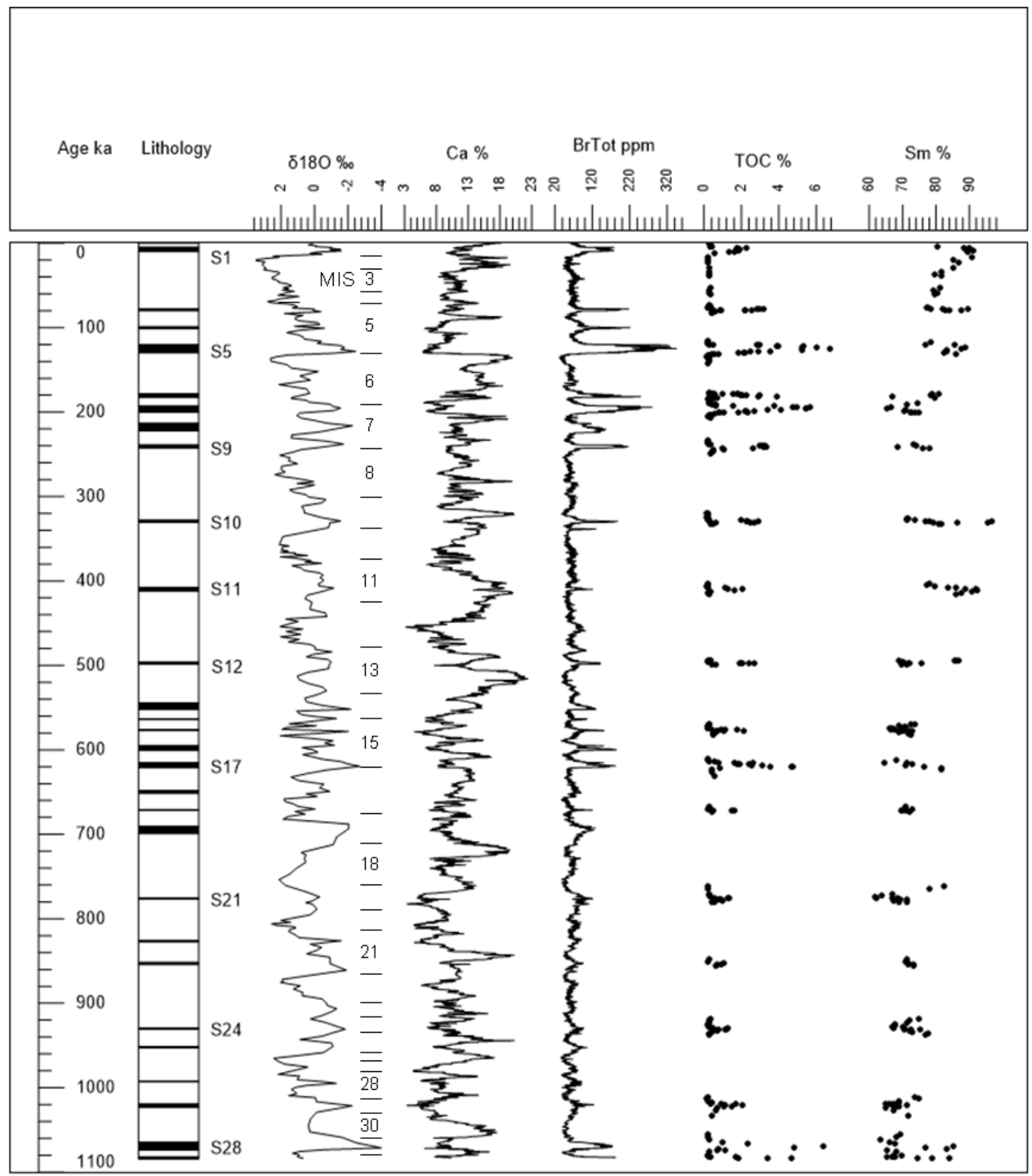

Figure 2 


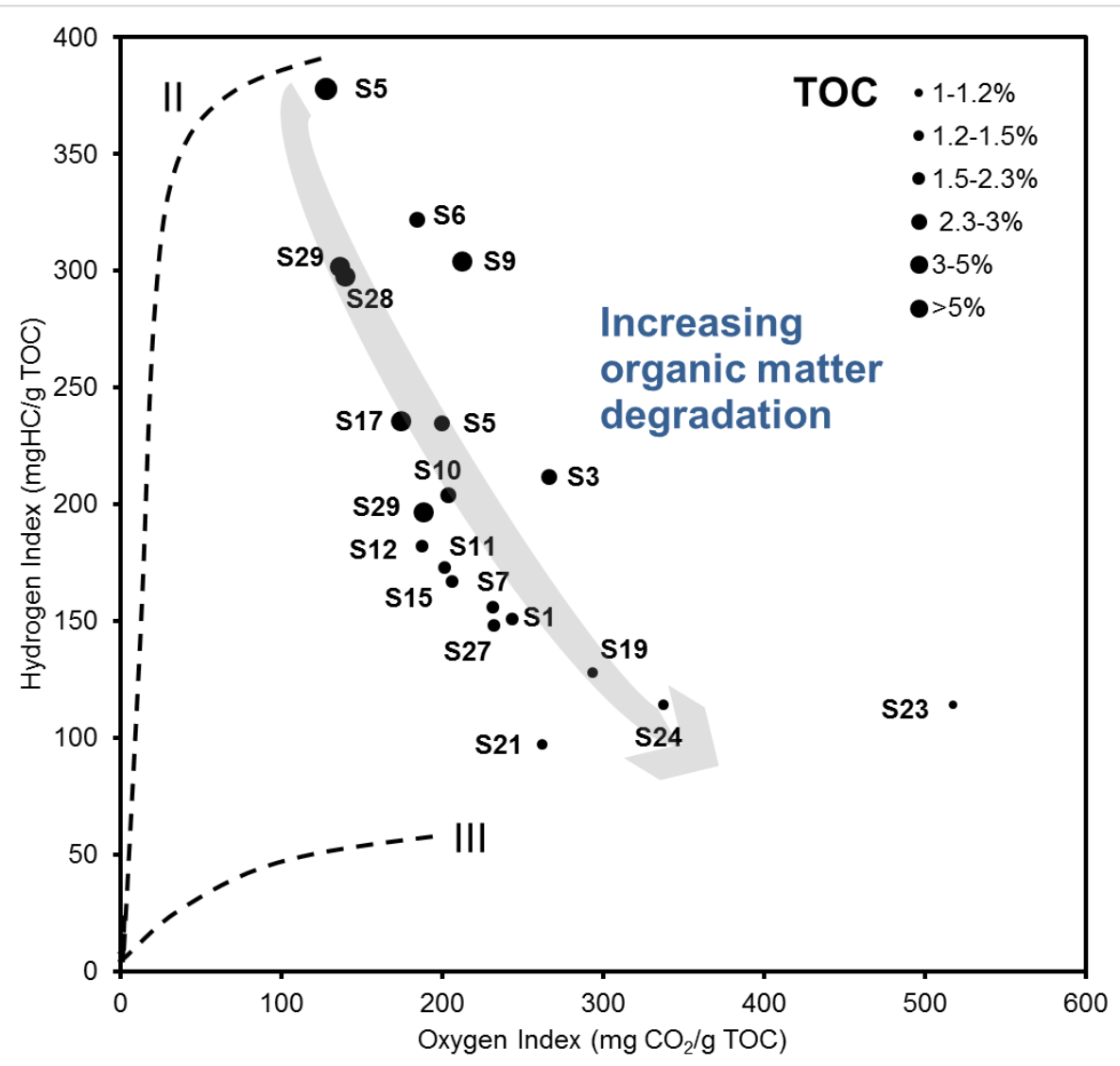

1001 Figure 3

1002 
1003

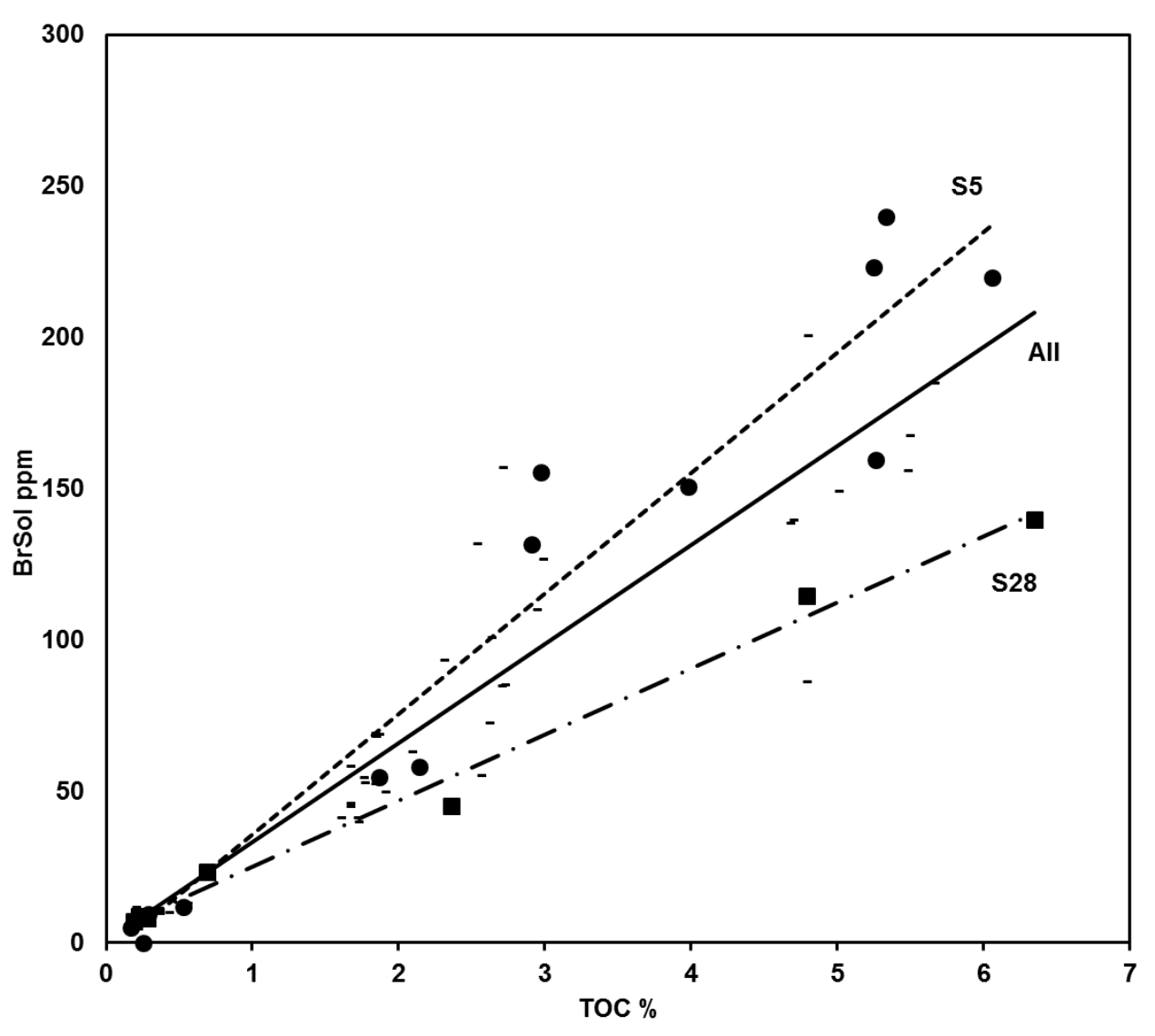

1004 Figure 4

1005 
1006

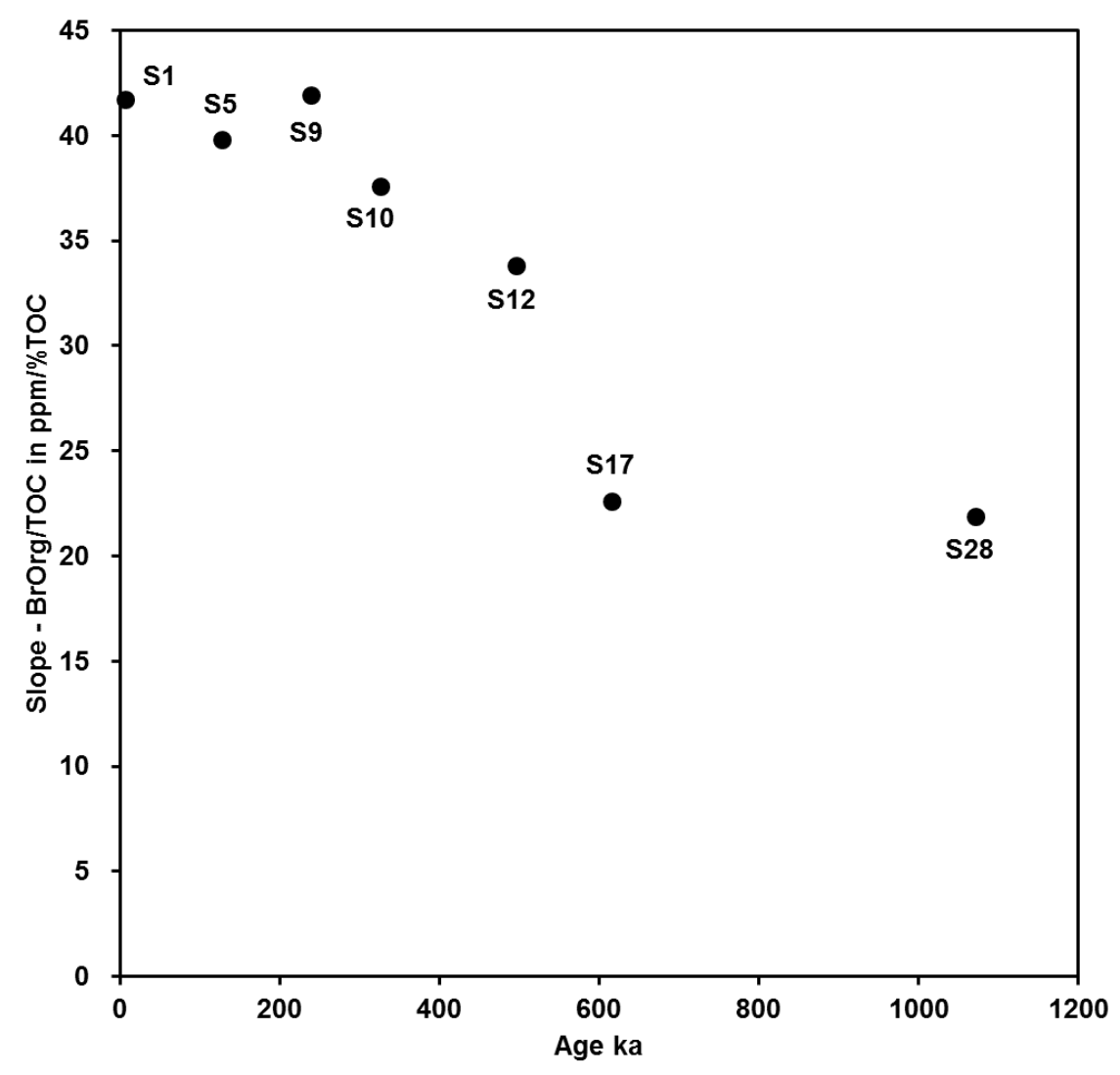

1007 Figure 5

1008 
1009

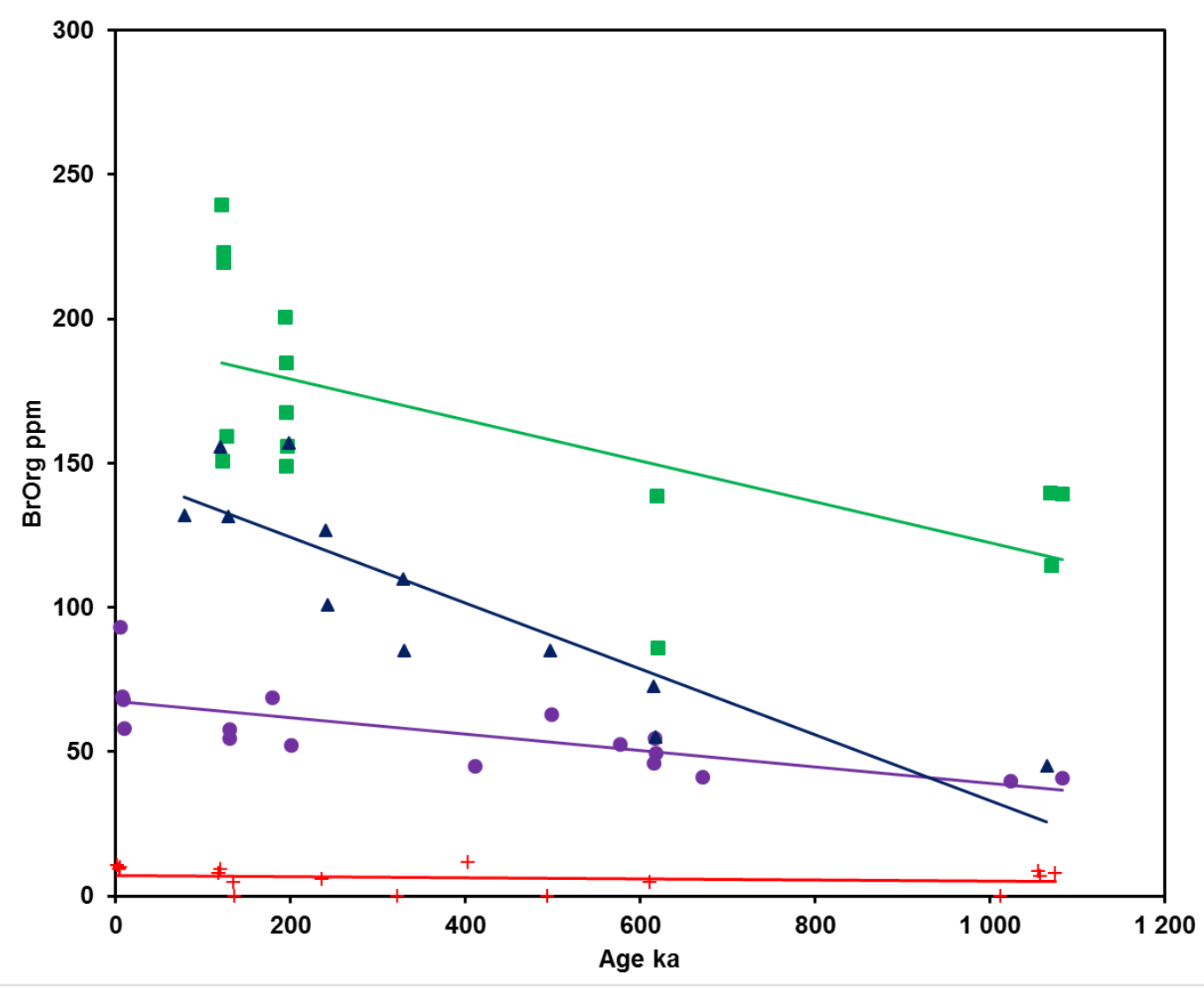

1010 Figure 6

1011 


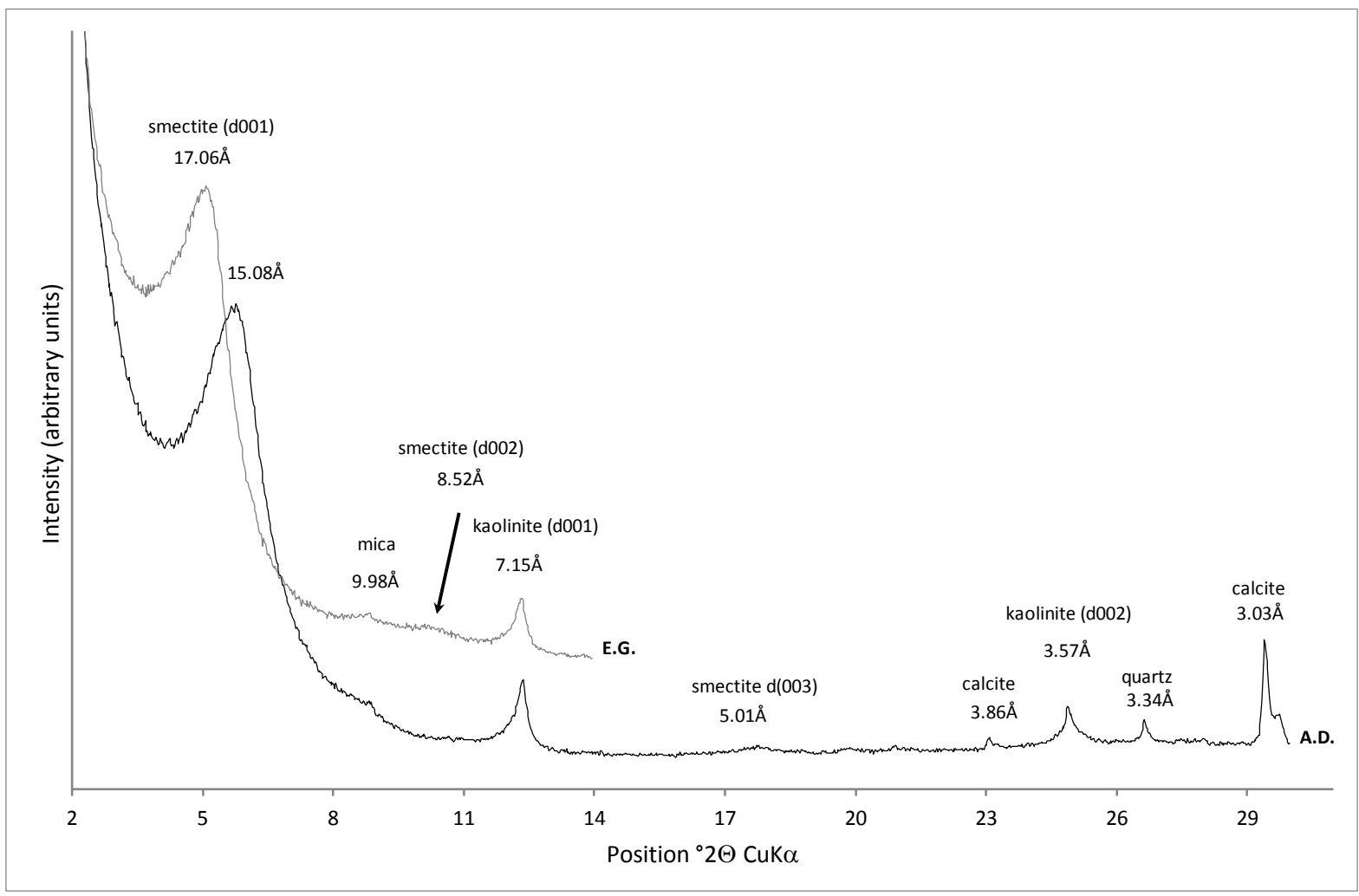

1013 Figure 7

1014 

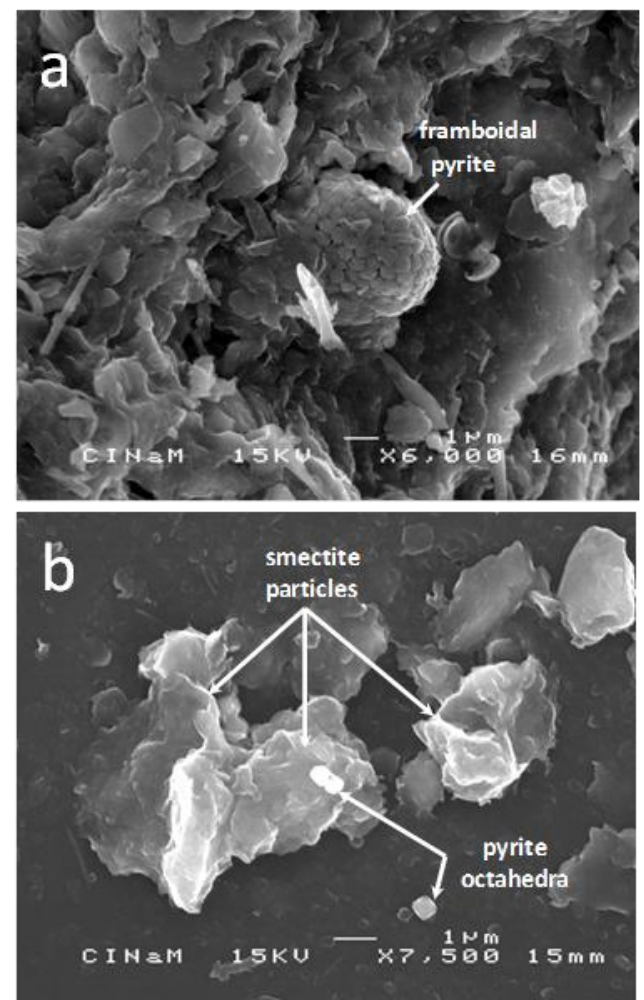

1015

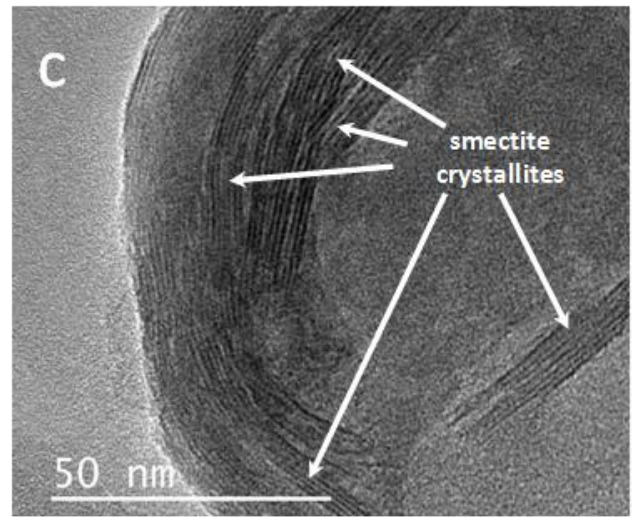

1016 Figure 8

1017 


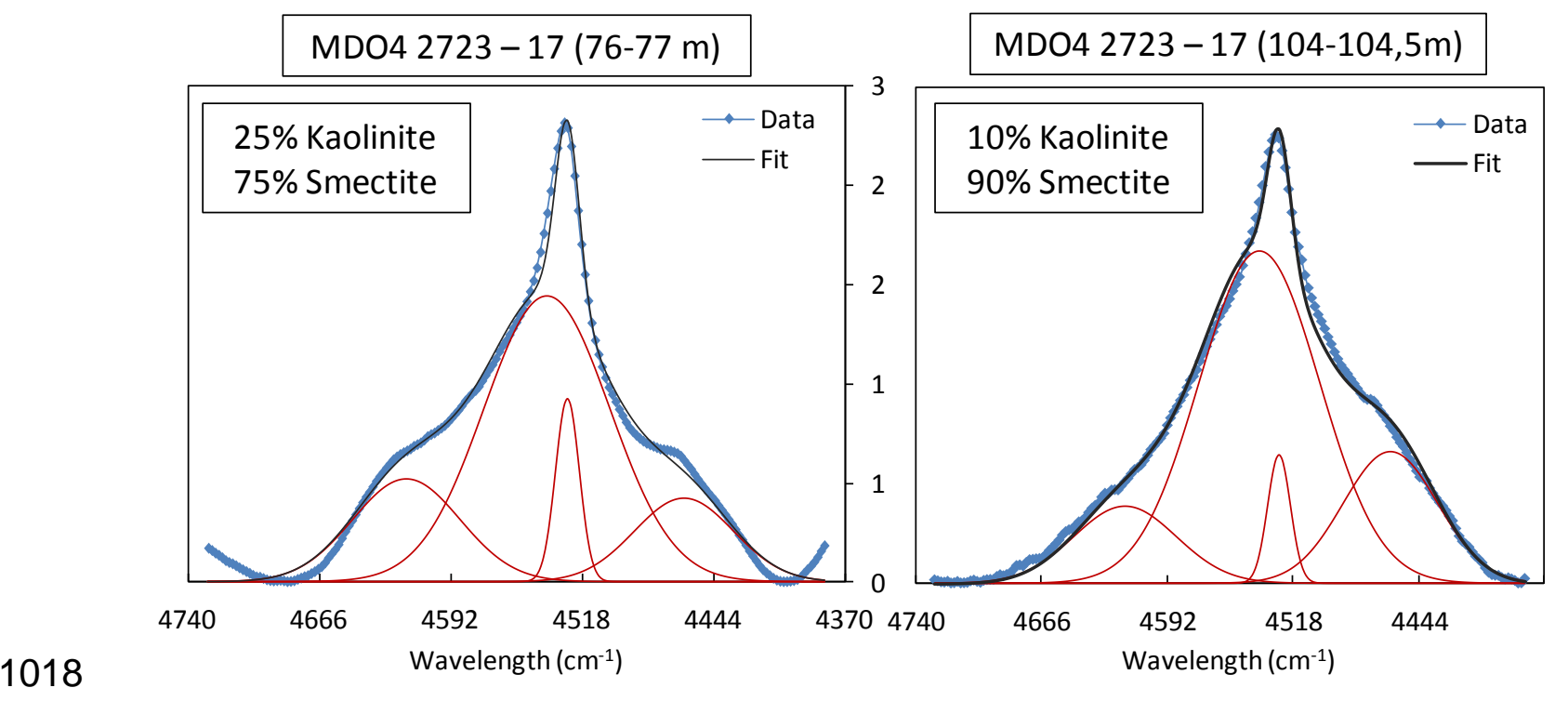

1019 Figure 9

1020 


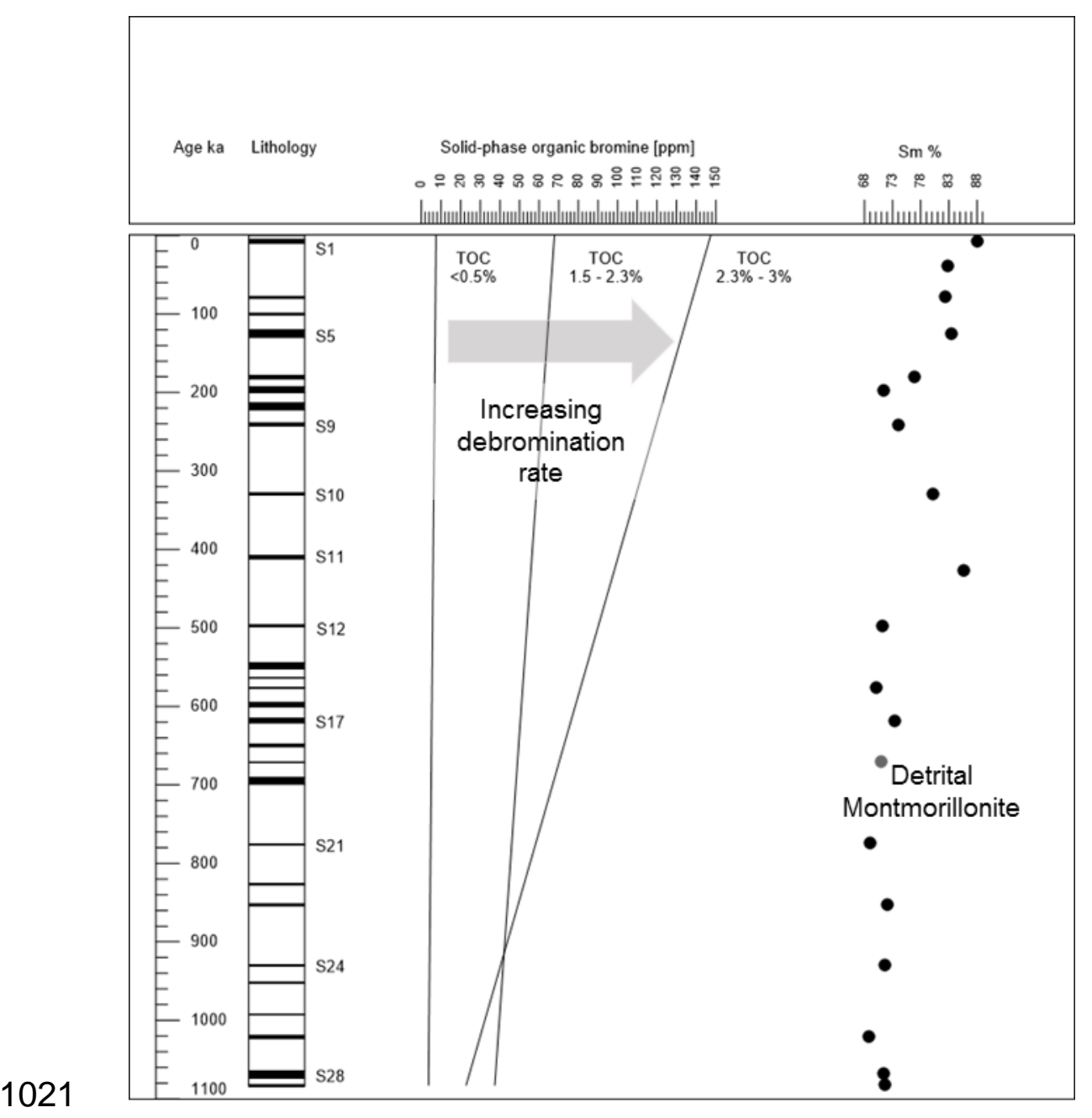

1022 Figure 10

1023 
1024 Table captions

1025 Table 1: Statistical results of the regression analysis of the TOC-BrOrg relationship. $1026 p>0.05$ is non significant (NS), $p$ between 0.05 and 0.01 is significant (S), $p$ between 10270.01 and 0.001 is highly significant (HS), and $p<0.001$ is very highly significant 1028 (VHS). The slope corresponds to the ratio of BrOrg to TOC in ppm/\%TOC.

1029 Table 2: Evolution of BrOrg with age by TOC range. Statistical results: $p>0.05$ is non 1030 significant (NS), $p$ between 0.05 and 0.01 is significant (S), $p$ between 0.01 and 10310.001 is highly significant (HS), and $p<0.001$ is very highly significant (VHS).

1032 Table 3: Representative structural formulas of smectite particles analyzed by TEM1033 EDX (1 and 2) and SEM-EDX(3-5). Number of ions calculated on the basis of 11 1034 oxygens ( $\mathrm{Fe}$ arbitrarily considered as $\mathrm{Fe}^{3+}$ ). Int. ch: interlayer charge. 
1036 Tables

\begin{tabular}{cccccccc}
\hline Sequence & Age $[\mathrm{ka}]$ & $\mathrm{N}$ & $\mathrm{r}$ & $\mathrm{r}^{2}$ & $p$-value & Slope & Intercept \\
\hline All data & & 63 & 0.922 & 0.851 & VHS & 32.8 & 0.44 \\
S1 & 6.13 & 8 & 0.996 & 0.993 & VHS & 41.7 & -6.83 \\
S5 & 127.47 & 14 & 0.968 & 0.937 & VHS & 39.8 & -3.90 \\
S9 & 238.94 & 3 & 0.996 & 0.992 & NS & 41.9 & -2.72 \\
S10 & 326.65 & 3 & 0.991 & 0.982 & NS & 37.6 & -7.51 \\
S12 & 495.89 & 3 & 0.999 & 0.999 & S & 33.8 & -6.86 \\
S17 & 615.48 & 8 & 0.909 & 0.825 & HS & 22.6 & 7.06 \\
S28 & 1071.57 & 7 & 0.995 & 0.990 & VHS & 21.9 & 3.13 \\
\hline
\end{tabular}

1038 Table 1

1039 


\begin{tabular}{|c|c|c|c|c|c|c|c|c|c|}
\hline TOC range & Mean TOC & $\mathrm{N}$ & $r$ & $r^{2}$ & $p$-value & Slope & Intercept & $\begin{array}{c}\% \text { of loss } \\
\text { BrOrg in } \\
1 \text { m.y. }\end{array}$ & $\begin{array}{c}\text { Debromination } \\
\text { rate }[\mu \mathrm{molBrOrg} \\
\left.\mathrm{molC}^{-1} \mathrm{y}^{-1}\right]\end{array}$ \\
\hline$<0.5 \%$ & 0.24 & 16 & -0.171 & 0.029 & NS & -0.002 & 6.92 & NS & NS \\
\hline $1.5-2.3 \%$ & 1.83 & 17 & -0.736 & 0.542 & HS & -0.028 & 67.53 & 41 & $2.310^{-4}$ \\
\hline $2.3-3.0 \%$ & 2.73 & 12 & -0.878 & 0.771 & HS & -0.115 & 147.46 & 78 & $6.310^{-4}$ \\
\hline $4.55-5.4 \%$ & 4.95 & 9 & -0.688 & 0.473 & $S$ & -0.087 & 201.34 & 43 & $2.610^{-4}$ \\
\hline $5.4-6.5 \%$ & 5.80 & 5 & -0.671 & 0.450 & NS & -0.051 & 192.07 & NS & NS \\
\hline $4.0-6.5 \%$ & 5.17 & 15 & -0.640 & 0.410 & $\mathrm{~S}$ & -0.071 & 193.31 & 37 & $2.010^{-4}$ \\
\hline
\end{tabular}

\section{Table 2}

1042 
1043

\begin{tabular}{|l|ccccc|}
\cline { 2 - 6 } \multicolumn{1}{c|}{} & 1 & 2 & 3 & 4 & 5 \\
\hline $\mathrm{Si}$ & 3.97 & 3.83 & 3.91 & 3.91 & 3.84 \\
$\mathrm{Al}^{\mathrm{IV}}$ & 0.03 & 0.17 & 0.09 & 0.09 & 0.16 \\
\hline $\mathrm{Al}^{\mathrm{VI}}$ & 1.24 & 1.14 & 1.35 & 0.88 & 1.45 \\
$\mathrm{Fe}^{3+}$ & 0.31 & 0.26 & 0.28 & 0.53 & 0.26 \\
$\mathrm{Mg}$ & 0.53 & 0.65 & 0.37 & 0.59 & 0.29 \\
\hline $\mathrm{Ca}$ & 0.09 & 0.17 & 0.03 & 0.05 & 0.14 \\
$\mathrm{Na}$ & 0.10 & 0.17 & 0.25 & 0.31 & 0.12 \\
$\mathrm{~K}$ & 0.06 & 0.14 & 0.14 & 0.26 & 0.07 \\
$\mathrm{Int}$ & & & & & \\
Ch. & 0.35 & 0.65 & 0.45 & 0.67 & 0.47 \\
\hline
\end{tabular}

1044 Table 3 